\title{
The Ins and Outs of Messenger RNA Electroporation for Physical Gene Delivery in Immune Cell-Based Therapy
}

\author{
Diana Campillo-Davo ${ }^{1, *}$, Maxime De Laere ${ }^{2}$, Gils Roex ${ }^{1}{ }^{\oplus}$, Maarten Versteven ${ }^{1}{ }^{\circledR}$, Donovan Flumens ${ }^{1}$, \\ Zwi N. Berneman ${ }^{1,2,3}$, Viggo F. I. Van Tendeloo ${ }^{1}\left(\mathbb{D}\right.$, Sébastien Anguille ${ }^{1,2,3}$ and Eva Lion ${ }^{1,2, *(1)}$ \\ 1 Tumor Immunology Group, Laboratory of Experimental Hematology, Faculty of Medicine and Health \\ Sciences, Vaccine \& Infectious Disease Institute (VAXINFECTIO), University of Antwerp, 2610 Wilrijk, \\ Belgium; Gils.Roex@uantwerpen.be (G.R.); maarten.versteven@uantwerpen.be (M.V.); \\ donovan.Flumens@uza.be (D.F.); zwi.berneman@uza.be (Z.N.B.); viggovantendeloo@gmail.com (V.F.I.V.T.); \\ sebastien.anguille@uantwerpen.be (S.A.) \\ 2 Center for Cell Therapy \& Regenerative Medicine, Antwerp University Hospital, 2650 Edegem, Belgium; \\ maxime.DeLaere@uza.be \\ 3 Division of Hematology, Antwerp University Hospital, 2650 Edegem, Belgium \\ * Correspondence: Diana.CampilloDavo@uantwerpen.be (D.C.-D.); Eva.Lion@uantwerpen.be (E.L.); \\ Tel.: +32-3821-5254 (D.C.-D.); +32-3821-4112 (E.L.)
}

check for updates

Citation: Campillo-Davo, D.; De Laere, M.; Roex, G.; Versteven, M.; Flumens, D.; Berneman, Z.N.; Van Tendeloo, V.F.I.; Anguille, S.; Lion, E. The Ins and Outs of Messenger RNA Electroporation for Physical Gene Delivery in Immune Cell-Based Therapy. Pharmaceutics 2021, 13, 396. https://doi.org/10.3390/

pharmaceutics13030396

Academic Editor: Satoshi Uchida

Received: 19 January 2021

Accepted: 10 March 2021

Published: 16 March 2021

Publisher's Note: MDPI stays neutral with regard to jurisdictional claims in published maps and institutional affiliations.

Copyright: (c) 2021 by the authors. Licensee MDPI, Basel, Switzerland. This article is an open access article distributed under the terms and conditions of the Creative Commons Attribution (CC BY) license (https:/ / creativecommons.org/licenses/by/ $4.0 /)$.

\begin{abstract}
Messenger RNA (mRNA) electroporation is a powerful tool for transient genetic modification of cells. This non-viral method of genetic engineering has been widely used in immunotherapy. Electroporation allows fine-tuning of transfection protocols for each cell type as well as introduction of multiple protein-coding mRNAs at once. As a pioneering group in mRNA electroporation, in this review, we provide an expert overview of the ins and outs of mRNA electroporation, discussing the different parameters involved in mRNA electroporation as well as the production of research-grade and production and application of clinical-grade mRNA for gene transfer in the context of cell-based immunotherapies.
\end{abstract}

Keywords: messenger RNA; gene delivery; electroporation; in vitro transcription; immune cellbased therapy

\section{Introduction}

Since the early experimental application of electric pulses in the field of medicine during the eighteenth century, electroporation has become a universal method for transfecting biological and synthetic compounds into an array of prokaryotic and eukaryotic cells for a wide number of purposes [1]. Electroporation, also called electropermeabilization, is defined as the application of voltage pulses that generate an electric field between two electrodes that disrupts the integrity of a cell membrane, allowing the formation of pores. It was first developed as an irreversible process of pore formation that did not allow recovery of the cell membrane, therefore resulting in cell death [1] Reversible electroporation was introduced in 1957 by Stämpfli and Willi [2], but it was not until 1982 that this type of electroporation was described for the transfection of genetic material [3]. In that article, Neumann et al., who also coined the term "electroporation", described how electric pulses enhanced the uptake of extracellular DNA into mouse cells [3]. Since then, the versatility of this technique has been demonstrated in multiple cell types and organisms for the transfection of various molecules in a wide range of applications. The field of cell-based immunotherapy in particular has made enormous progress due to the development and optimization of messenger RNA (mRNA) electroporation for gene transfer. This type of genetic engineering, compared to that of the viral delivery of genes, represents a safer alternative for protein expression with no risk of insertional mutagenesis and lower immunogenicity $[4,5]$. The superiority of mRNA electroporation over passive pulsing or lipofection of mRNA, and even over plasmid DNA electroporation, in terms of efficiency 
of gene delivery was demonstrated by our group two decades ago [6,7]. In contrast to plasmid DNA electroporation, transient gene expression linked to the natural decay of introduced mRNA provides an accurate system to control the synthesis of exogenous proteins. The main factors involved in successful mRNA electroporation for gene transfer can be divided into three main categories, (i) electroporation parameters, (ii) variables of in vitro mRNA synthesis, and (iii) elements used to enhance transfected mRNA stability and transgene expression (Figure 1). In this review, we discuss the different parameters marking mRNA electroporation and how to implement them as well as the factors involved in the production of clinical-grade mRNA for electroporation in the context of cell-based immunotherapies.

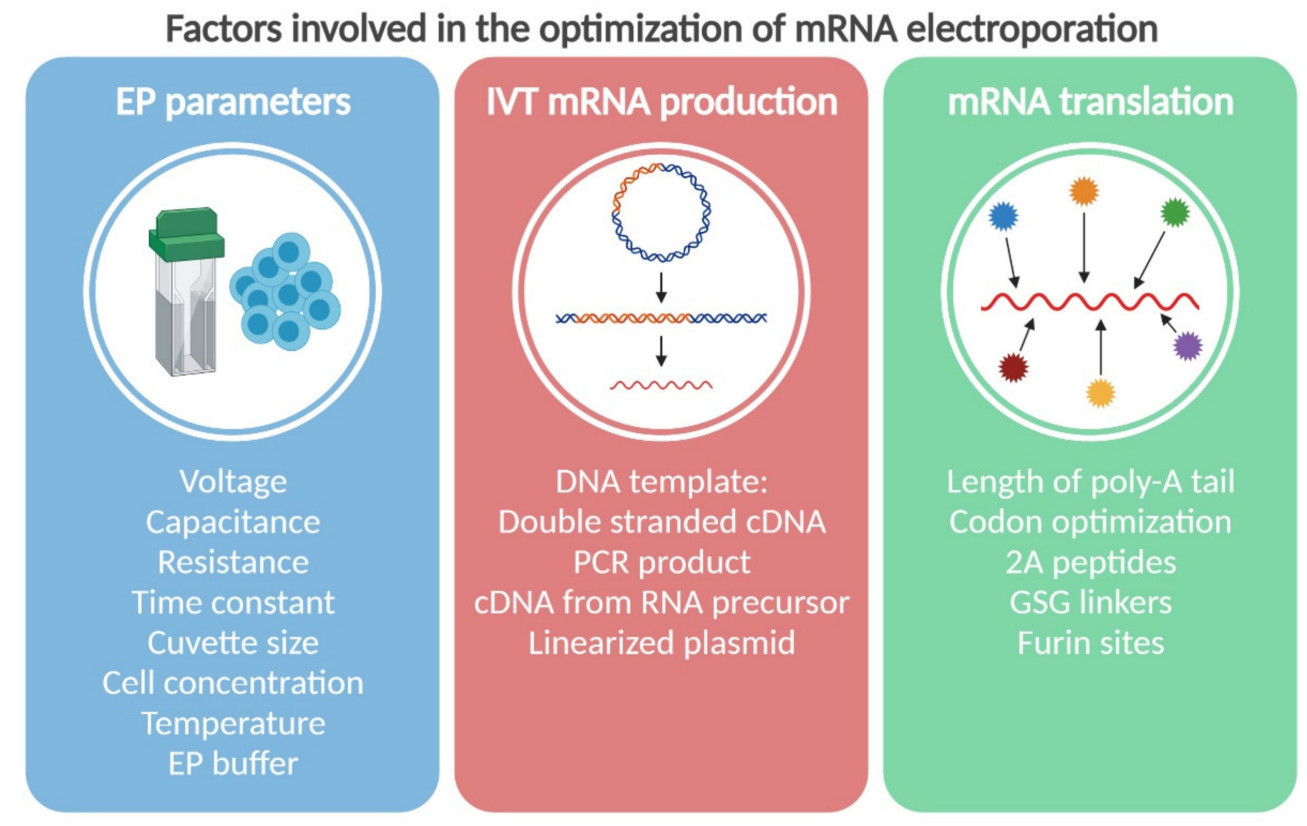

Figure 1. Overview of the main factors that influence the success of a messenger (mRNA) electroporation-based therapy. Several factors may influence the transfection efficiency (blue), synthesis (red) and translation (green) of mRNA in electroporation-based therapies. These factors can be individually optimized, combined and tailored for each type of immune cell and target gene to be transferred. EP, electroporation; IVT, in vitro transcription; cDNA, complementary DNA; PCR, polymerase chain reaction. Created with BioRender.com.

\section{The Physics: Parameters of Electroporation}

Electrical disruption of a cell membrane causes the formation of pores through which nucleic acids, proteins, and other small molecules present in the environment surrounding the cells can permeate, gaining access to the intracellular space (Figure 2). In vitro electroporation of immune cells is carried out using a pulse generator (or electroporator). Generally, cells are placed in sterile cuvettes consisting of a cell chamber with two parallel metal electrode plates. Commercially available cuvettes for the transfection of mammalian cells typically have a gap size of 2 or $4 \mathrm{~mm}$. The difference in electric potential between the two electrodes is called voltage $(V)$ and it is measured in volts $(\mathrm{V})$. Before electroporation, cell membranes are in a non-permeable state that is characterized by low conductivity, dielectrical constant, and polarizability [8]. As mentioned in the previous section, a voltage pulse is applied during the electroporation process. This generates an electric field that creates a linear strength gradient between the electrodes. The voltage used divided by the gap size of the cuvette determines the electric field strength $(E)$, commonly expressed in kilovolts per centimeter $(\mathrm{kV} / \mathrm{cm})$. That electric field will create an induced cell membrane potential. If the field strength is high enough, the induced cell membrane potential will surpass a threshold potential in which the cell membrane will undergo polarization and 
dielectric breakdown followed by an increase in membrane conductivity and permeability [9]. These changes allow the creation of hydrophilic nanopores through which ions in aqueous solutions may pass [10] (Figure 2). That flow of extracellular components will lead to the formation of larger pores allowing the passage of larger molecules such as RNA [10]. Moreover, ions moving from the positive electrode to the negative electrode will create electrophoretic forces that allow RNA (a polyanion) to travel to the positive electrode [8]. The induced cell membrane potential is not uniform nor permeabilization occurs homogenously across the membrane $[8,11]$. In fact, more pores will be created at the side of the cell membrane that faces the negative electrode, whereas, at the side of the positive electrode, a larger area of the cell membrane will be permeabilized (Figure 2). When the electric field is removed at the end of the electroporation process, resealing of the cell membrane occurs. Contrary to pore formation, which takes place within milliseconds, resealing of the cell membrane may take from minutes to hours [8]. When a critical field strength is reached, resealing of the cell membrane may not be possible, leading to cell death.

The electroporation process is also influenced by other parameters, including the capacitance, resistance, time constant, and pulse duration [12]. Capacitance (C), measured in microfarads $(\mu \mathrm{F})$, is defined as the ability of a capacitor-in this case, the membrane of the cells in suspension - to retain a charge $(Q)$ in the form of a potential difference or voltage. Accordingly, capacitance follows the equation: $C=Q / V$. Resistance $(R)$, expressed in ohms $(\Omega)$, is the force against the electrical current, which is influenced by elements such as the cell suspension or electroporation buffer. Taking into account these parameters, two types of pulses (or waveforms) are commonly used for electroporation of immune cells, exponential decay and square waves (Figure 2). Exponential decay is a pulse in which the chosen voltage is reached at the beginning of the pulse followed by an exponential and rapid decrease to zero [12]. That decay follows the formula:

$$
V_{t}=V_{0}\left(e^{-(t / \tau)}\right),
$$

where $V_{0}$ is the initial voltage at which the capacitor is charged, $V_{t}$ is the voltage at a time $t$, and $\tau$ is the time constant at which the voltage of the pulse has decreased from $V_{0}$ to $V_{0} / e$ [12]. The time constant results from the combination of the resistance and capacitance $(\tau=R \times C)$. The time constant should not be confused with pulse length or duration of the pulse $(\tau)$. An alternative form of exponential decay pulse-usually called "time constant" applies a voltage for a certain amount of time without constraining the capacitance. When the time is kept constant, the capacitance is adjusted to reach a particular (constant) pulse length for all the test conditions, which is dependent on the resistance of the cell suspension and the volume in the cuvette. In contrast, the square wave pulse, which gets its name from the shape of its electric potential curve, maintains the same voltage for the entire duration of the pulse after which it returns to a voltage of zero [12]. With this type of wave, it is possible to apply multiple and repeated electric pulses during a single electroporation.

The electric field strength, together with the duration of the pulse, is key in maintaining cell viability and transfection efficiency during electroporation (reviewed by [13]). Apart from its implications regarding the field strength, gap size will also determine the electroporation buffer volume and number of cells a cuvette can contain. Thus, widening the gap size will increase the usable volume and number of cells, but it will also reduce the field strength. Other parameters affecting the success of electroporation include the electroporation buffer used, the temperature of the different components during electroporation, and the cell concentration. The conductivity of the electroporation buffer, marked by its salt content, and the cell concentration are two of the main parameters that affect the resistance of the sample during electroporation [14]. Moreover, the composition of the buffer, especially the content in salts and sugars, may have a negative effect on cell viability and transfection efficiency [15-17]. Related to this, the presence of remaining salts in the cell and nucleic acid suspension may increase the final concentration of salts in the 
electroporation mixture leading to arcing [18]. Arcing is a complete or partial discharge of an electric current in a sample easily recognizable as an audible popping sound. This phenomenon occurs in the presence of high salt concentrations, but also in the presence of bubbles, of oil on the electrodes of the cuvettes due to handling without gloves, or with faulty cuvettes in combination with high voltages, and negatively impacts cell viability. The temperature of the electroporation buffer, cuvette, and cells is another variable to be considered during the optimization of electroporation conditions [12]. For example, keeping the cell suspension on ice or at $4{ }^{\circ} \mathrm{C}$ may limit membrane plasticity, reducing electroporation efficiency; however, cell viability and yield are often improved at lower temperatures. With respect to the recovery medium after permeabilization, there is no clear rule; however, a general recommendation to improve cell viability and pore resealing, which occurs within seconds, is the addition of human or non-human serum, depending on the experimental requirements [19]. Taken together, each of these parameters and elements of electroporation can be optimized to improve the efficiency of mRNA delivery while maintaining cell viability and yield $[12,20,21]$.

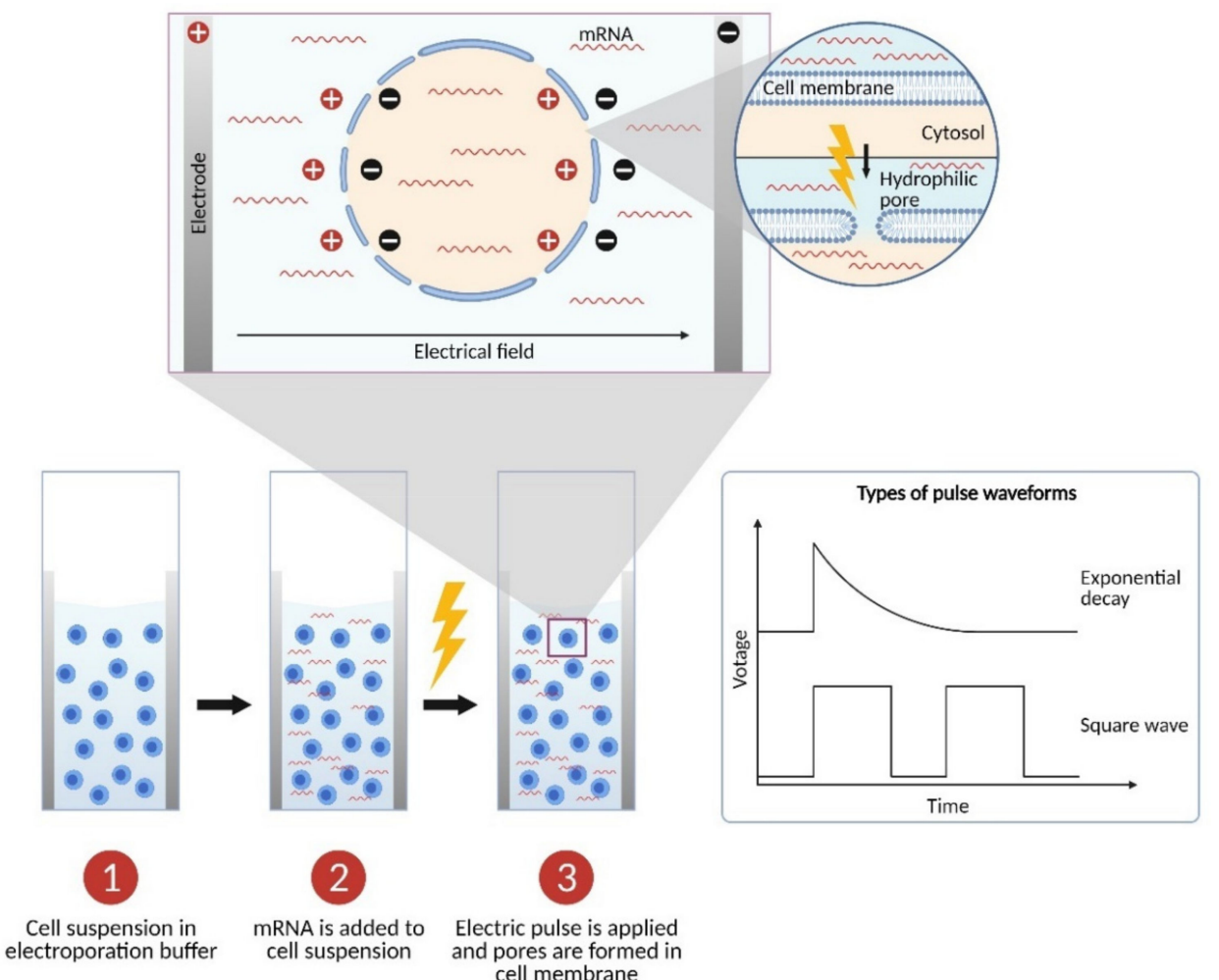

Figure 2. Elements of the electroporation process. The electroporation cuvettes contain two parallel electrodes separated by a gap where the cell suspension is placed. The cells that are in suspension in an electroporation buffer (1) are mixed with mRNA (2) and pulsed (3) with one of the two main types of electric waves: the exponential decay or the square wave. During the electric pulse, pores are transiently formed in the cell membrane through which the mRNA can flow into the cytosol. Created with BioRender.com.

\section{The Chemistry: In Vitro Synthesis of mRNA for Electroporation}

For mRNA electroporation in gene transfer studies, one of the key factors at the molecular level for efficient and correct protein expression is the synthesis of the mRNA. In eukaryotic cells, the first step of gene expression occurs in the nucleus and consists of the transcription of an mRNA strand from a segment of complementary DNA (cDNA) by RNA polymerase II. Before being transported to the cytoplasm to be translated into protein, the precursor mRNAs (pre-mRNAs) undergo a maturation process in the nucleus that includes modification of the $5^{\prime}$ and $3^{\prime}$ ends and elimination of the non-coding regions 
(introns). The first modification occurs at the $5^{\prime}$ region where a methylated guanosine or "cap" is added to the first nucleotide of the pre-mRNA, protecting it from degradation by exonucleases [22]. Next, polyadenylation takes place at the $3^{\prime}$ terminus of the premRNA [23]. Finally, the introns are removed from the pre-mRNA through splicing, leaving a mature mRNA consisting of the protein-coding regions (exons) flanked by untranslated regions (UTRs), the methylated guanosine cap, and a poly(A) tail.

The $3^{\prime}$ UTR region of the mRNA is a primary factor influencing its cellular localization, stability, and translation efficiency [24]. Messenger RNAs encoding the same protein can exhibit different $3^{\prime}$ UTR isoforms depending on the specific intended fate of a particular mRNA. Importantly, the length and composition of the $3^{\prime}$ UTR region help regulate the mRNA, and thereby the protein levels in a cell at any given time. In fact, the $3^{\prime}$ UTR region, together with the $5^{\prime}$ cap, is indispensable for the formation of the stem-loop structure needed to initiate mRNA translation. Shorter $3^{\prime}$ UTRs have an advantage in the formation of the initiation loop compared to that of mRNAs with longer $3^{\prime}$ UTRs. In the nucleus, polyadenylation of mRNAs on their $3^{\prime}$ side is a tightly regulated and standardized process that results in the addition of approximately 200 nucleotides in mammals [25]. The length of the poly(A) tail is usually shortened after the mRNA enters the cytoplasm through a mechanism that is involved in regulating mRNA decay [26]. Actually, the poly(A) tail is a dynamic region of the mRNA sequence that is affected by the processes of adenylation (to lengthen) and deadenylation (to shorten), which are adjusted during different stages of the cell cycle or in response to specific signals. The effect of poly(A) tail length on translational control has been previously reviewed by Weill et al. [27].

Most natural mRNAs are degraded by endonucleases or exonucleases within minutes or hours of being transcribed. However, transcripts that encode proteins which are functionally vital for the cell are usually more stable. An important determinant of mRNA stability lies in the portion of the $3^{\prime}$ UTR preceding the poly(A) tail. In particular, human globin mRNAs have been characterized as being highly stable with half-lives up to 48 $h$ due to their $3^{\prime}$ UTR [28]. Therefore, the addition of these $3^{\prime}$ UTR motifs to synthetic mRNAs benefits their stability, resulting in higher protein expression levels [29]. In situations where increased protein translation is needed without wanting to affect the mRNA half-life, addition of the cytochrome b-245 alpha chain gene $3^{\prime}$ UTR may be a suitable candidate [30]. In the laboratory, mRNA synthesis is commonly performed via in vitro transcription (IVT), a rapid and efficient technique that yields high amounts of mRNA. The open reading frame (ORF) of the therapeutic gene of interest is preceded by a $5^{\prime}$ UTR containing a promoter and the Kozak sequence [31]. The promoter is usually specific for bacteriophage SP6, T3, or T7 RNA polymerase [32-35]. The Kozak consensus elements, called the Shine-Dalgarno sequence in prokaryotes, are the nucleotides preceding and following the AUG start codon. These sequences at the proper position in vertebrates act as enhancers of initiation of translation [36]. The ORF of the gene of interest is followed by a $3^{\prime}$ UTR and a poly(A) tail, depending on the template used. The $3^{\prime}$ UTR and a poly A tail are elements crucial for the stability and translational efficiency of the produced mRNA. To generate IVT mRNA, there is a broad range of commercially available IVT kits; however, the basic requirements to initiate transcription are a purified cDNA template, ribonucleotide triphosphates, distilled water, reaction buffer, and an RNA polymerase. The double-stranded cDNA template is typically a product of polymerase chain reaction (PCR), cDNA from an RNA precursor, or a linearized plasmid DNA (Figure 3). In the case of PCR products, the gene of interest is amplified by PCR using a plasmid or genomic DNA as template. Then, through the addition of the appropriate primers and another round of PCR amplification, the cDNA template is linked to a promoter for the ultimate translation of the ORF [37]. This is done by including at the $5^{\prime}$ end of one of the primers the promoter region of an RNA polymerase from one of the bacteriophages. When using cDNA generated from an RNA precursor, the RNA first undergoes a reverse transcription reaction with primers containing the bacteriophage polymerase, resulting in the production of a single DNA strand bound to the RNA precursor. The second cDNA strand is then 
generated using the complementary RNA as primer to form the double-stranded DNA. For plasmids, the circular DNA is linearized by digestion with a restriction enzyme prior to IVT, to prevent the transcription of the entire plasmid sequence. This results in the creation of either blunt end or sticky $3^{\prime}$-overhanging ends, depending on the enzyme used. Related to this, an important concern after plasmid linearization is the addition of non-adenine nucleotides to the poly(A) tail from the overhanging ends, which otherwise will reduce translation efficiency. To avoid non-adenine nucleotides at the end of the poly(A) tail, type IIS restriction enzymes can be used instead of the classical type II enzymes as type IIS enzymes cleave the DNA sequence outside the recognition site and create blunt ends without $3^{\prime}$ overhangs. A detailed protocol has been previously published [38].

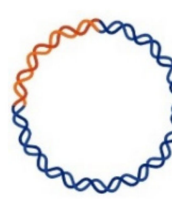

Linearization
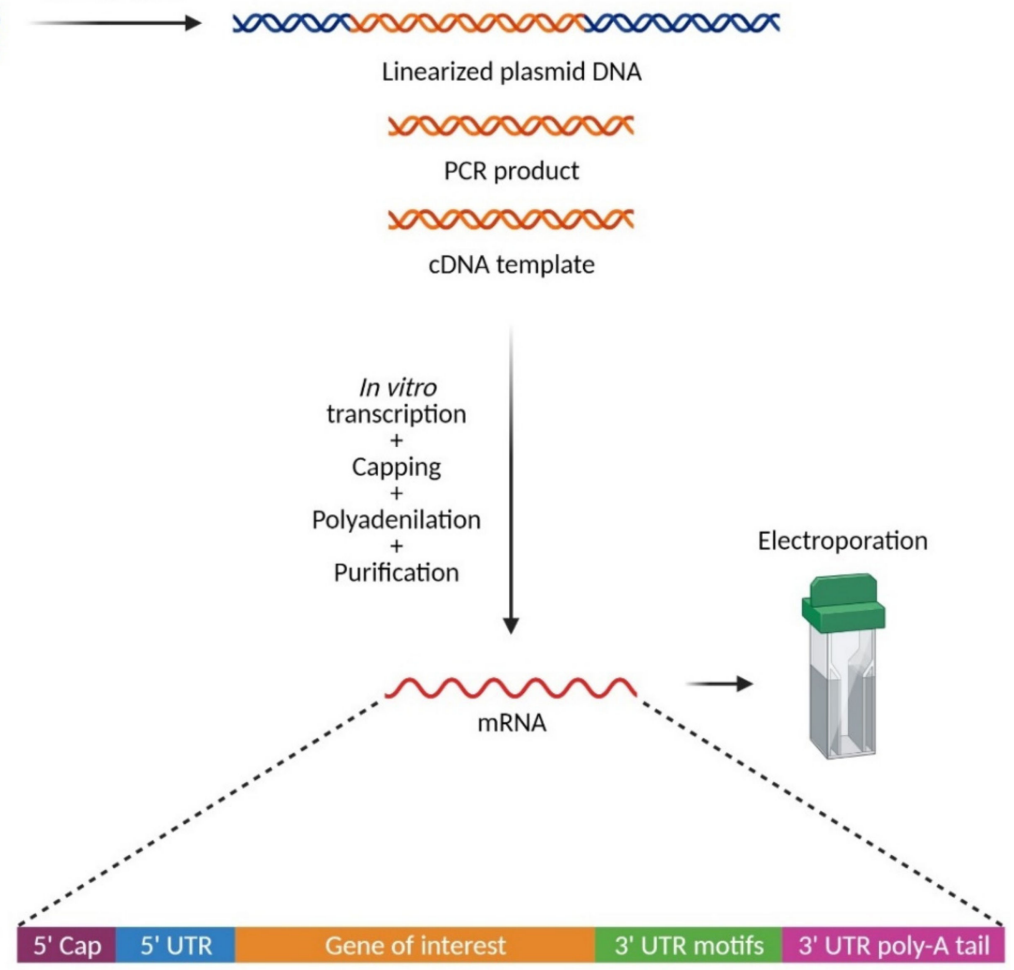

Figure 3. Basic workflow for mRNA synthesis. The in vitro synthesis of mRNA starts with the preparation of the DNA template containing the gene of interest (depicted in orange), which can be linearized plasmid DNA, a PCR product, or a cDNA template. These DNA templates will be used for the in vitro transcription of mRNA using an RNA polymerase, followed by mRNA capping at the $5^{\prime}$ untranslated region, addition of a poly(A) tail at the $3^{\prime}$ untranslated region (optional in cases were a poly(A) is included in the DNA template), and purification of the final mRNA. UTR, untranslated regions. Created with BioRender.com.

\section{The Biology: How to Improve mRNAs for Better Stability and Translation}

Apart from optimizing the electroporation conditions and choosing the best template for mRNA production, other factors also contribute to successful mRNA stability and translation and should be considered to improve protein expression in electroporated cells. As described in the previous section, mRNA capping and polyadenylation are indispensable for successful mRNA translation. The $5^{\prime}$ capping of IVT mRNA can be directly done during RNA generation or done separately. The various options for $5^{\prime}$ capping have been reviewed elsewhere [39]. When polyadenylation is performed separately after IVT, mRNAs are formed with a greater variability in poly(A) tail length. In other cases, the poly(A) tail is cloned into the plasmid and positioned within the construct after the ORF. Since poly(A) tails are shortened in the cytoplasm due to natural mRNA degradation, different 
plasmids have been developed based on the extension of the poly(A) tails to improve mRNA yield and stability. For example, the pST1-A120 vector includes a poly(A) tail of $\sim 120$ base pairs (bp) [29], and the plasmid pEVL can be used to increase the poly(A) tail length up to $\sim 500 \mathrm{bp}$ [40]. Some plasmids for in vitro synthesis of RNA can be purchased from commercial sources, such as $\mathrm{pGEM}-\mathrm{XZ}$ and $\mathrm{pSPXX}$ vector series (Promega), $\mathrm{pBlue}-$ script II phagemid vectors (Agilent), pCRII and pTRIPLEscript vectors (Invitrogen) [41], pT7-mRNA vector (VectorBuilder Inc.), and pMRNAxp mRNAExpress vector (System Biosciences). Another factor that improves mRNA translation is codon optimization. Some mRNAs may contain "rare" codons that decrease the rate of translation, an issue that has been previously reviewed [42]. Codon optimization involves replacing those codons with more highly expressed synonymous codons, thereby enhancing protein expression compared to that of the native sequences [43].

Gene transfer using mRNAs may encode for multiple proteins at the same time, similar to what can be done using DNA vectors. Over the years, various strategies have been used in gene therapy to yield individual translation products from polycistronic constructs [44]. Two of the most common strategies are the insertion of internal ribosome entry sites (IRES) and self-cleaving 2A peptides sequences between the genes. IRES were first discovered in picornavirus and allow cap-independent translation of proteins (reviewed by [45]). Placed between two independent sequences, IRES are able to recruit ribosomes to initiate the translation of the downstream genes [45]. However, due to the large size and inconsistent translation rates of IRES, this system has become less popular in mRNA gene transfer in favor of 2A peptides [46,47]. Initially found in picornavirus, 2A peptides are 18-22 amino acid-long oligopeptides that are part of the ribosome "skipping" translational mechanism [46]. They allow for the stoichiometric expression of upstream and downstream genes in bicistronic cassettes and exhibit a high cleaving efficiency with minimal addition of amino acids to the translated proteins. Among the various 2A peptides, $\mathrm{P} 2 \mathrm{~A}$ from porcine teschovirus-1 and T2A from Thosea asigna virus usually yield better results in comparative studies than that of other 2A peptides, such as F2A from foot-and-mouth disease virus or E2A from equine rhinitis A virus [46]. Multiple 2A peptides can also be used together in multicistronic constructs, resulting in different gene expression levels depending on the combination of peptides used [48]. An important factor that may limit cleavage efficiency is the $\mathrm{C}$-terminal sequence preceding the $2 \mathrm{~A}$ peptide $[49,50]$. Frequently, $2 \mathrm{~A}$ peptides are preceded by flexible oligopeptide linkers that are comprised of combinations of glycine and serine, in many cases being the combination Gly-Ser-Gly [50,51]. These spacers improve the cleaving efficiency of the 2A peptides, resulting in the correct expression of the upstream and downstream proteins [50-52]. However, they also add a few more amino acids to the C-terminus of the upstream protein, potentially having functional consequences that must be assessed on a case-by-case situation. A solution to this problem is the addition of furin recognition sites before the $2 \mathrm{~A}$ peptide $[52,53]$. Furin is an endoprotease that recognizes $\mathrm{RX}(\mathrm{K} / \mathrm{R}) \mathrm{R}$ motifs. The $2 \mathrm{~A}$ peptides, glycine-serine linkers, and furin cleavage sites can be used simultaneously $[51,52]$. However, it is important to note that they must be in a single ORF with the genes of interest either before and/or after them. This ensures the correct translation and expression of the transferred proteins.

\section{Clinical Production of mRNA for Electroporation}

In general, two types of clinical-grade mRNA can be distinguished: documentedgrade [54] and good manufacturing practice (GMP)-grade mRNA. These two categories of mRNA vary in the regulatory aspects associated with their production, which are determined by the intended usage of the mRNA (i.e., as a starting material or as a medicinal product), the class of advanced therapy medicinal product (ATMP) the final product belongs to (i.e., cell-based ATMP or gene therapy product), and the stage of development of the medicinal product (i.e., investigational or marketed). In the context of mRNA transfection for immune cell-based immunotherapeutics, mRNA can be considered both starting material and active substance for the generation of a cell-based ATMP. While Directive 
2001/83/EC [55], as amended, holds the obligation for the manufacturing authorization holders to use only active substances that have been manufactured in accordance with GMP for starting materials, Directive 2005/28/EC includes no such requirement for manufacturers of investigational medicinal products [56]. For this reason, mRNA not fully complying with the GMP requirements, but of which the quality is controlled and documented in such a way that it justifies its use in the clinical setting (i.e., documented-grade mRNA) is a valid starting material for the production of mRNA-modified cell-based investigational medicinal products. For any other clinical application, GMP-grade mRNA is required, according to the applicable regulatory guidelines. Guidance on the interpretation of the GMP principles and guidelines for active substances used as starting materials are described in "The Rules Governing Medicinal Products in the European Union" (EudraLex), Volume 4 "Good Manufacturing Practice", Part II "Basic Requirements for Active Substances used as Starting Materials" as laid down in Directive 2003/94/EC [57].

For the production of GMP-grade mRNA, an extensive documented quality management system needs to be established. This system should cover the complete process of active pharmaceutical ingredient (API) manufacturing, from qualification of raw material suppliers, overproduction, quality control, release of intermediates and the API, to API packaging, labeling, storage, and distribution. The EudraLex GMP guidelines in addition set standards for manufacturing premises, process equipment, and personnel, while also covering administrative aspects such as record keeping, change and deviation management, and corrective action and preventive action (CAPA) system. To ensure the highest quality of the produced mRNA, each batch is subjected to extensive QC testing, which commonly includes assays for integrity, identity, potency, and, as appropriate, sterility and the presence of bacterial endotoxins (Figure 4). QC tests related to detection of relevant impurities, such as residual solvents, proteins, template and/or bacterial DNA, and other mRNA properties (e.g., capping efficiency) depend on the manufacturing process selected and the desired/required degree of control. These procedures should be validated, taking into consideration the relevant guidance and recommendations found in the International Council for Harmonization of Technical Requirements for Pharmaceuticals for Human Use (ICH) Q2 (R1) guidelines (CPMP/ICH/381/95) [58]. The EudraLex GMP guide also includes recommendations (with no obligatory force) for starting materials used in the production of investigational medicinal products. While it is recognized that not all GMP standards are applicable in early clinical development and a certain level of flexibility is required in this phase, manufacturers should still ensure that appropriate GMP concepts are applied in the production of APIs for use in clinical trials and that compliance increases with the stage of development.

From the above, it is evident that producing clinical-grade mRNA requires dedicated infrastructure, equipment, and expertise. Hence, many investigators outsource this activity and purchase customized clinical-grade IVT mRNA from specialized commercial suppliers. Currently, different companies provide these services, which include BioNTech, Biomay CureVac, EtheRNA, and Eurogentec in Europe, and Aldevron, Creative Biolabs, Moderna, and TriLink in the United States of America. Our research group has extensive experience in different clinical trials involving the use of mRNA as API starting material (ClinicalTrials.gov reference number NCT00834002, NCT00965224, NCT01291420, NCT01686334, NCT02649582, NCT02649829). From these clinical studies, we have learned that the service of customized clinical-grade mRNA production is associated with very high costs and extended turn-around-times for production and delivery. This is at least in part due to the fact that, while the amounts of mRNA as API required in the context of early phase clinical trials are relatively small, substantially higher amounts of mRNA need to be produced, at cost, to comply with GMP quality control and stability testing requirements. In this perspective, in-house production of small to medium batches of documented-grade mRNA, which is less demanding in terms of required infrastructure and overall GMP compliance, may provide clinical research centers with an alternative to support their early clinical development needs. It has to be taken into account, however, that any change to 
the API at a later stage of development made in view of meeting the increasing regulatory requirements, results in the need for comparability studies to ensure these changes do not alter the final cell therapy product. Still, the significantly reduced cost associated with in-house production of documented-grade mRNA versus custom-produced GMP-grade mRNA may ensure sustainability of research efforts focusing on mRNA-electroporated cell-based immunotherapeutics.

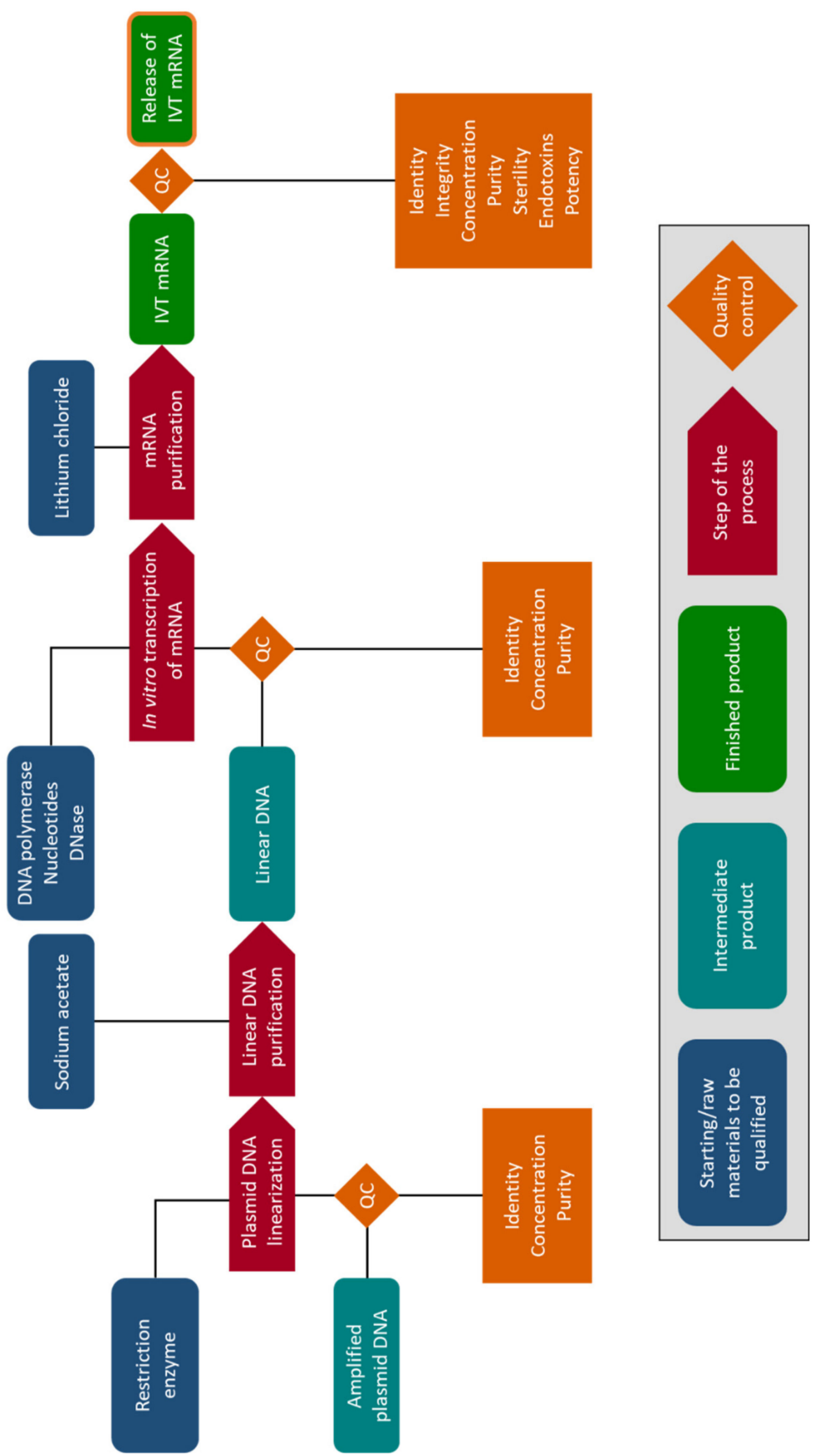

Figure 4. Example of the messenger RNA production processes and quality control testing for the release of IVT mRNA in a clinical setting for human use. Generally, different reagents, raw materials, and intermediate products are needed to produce any in vitro transcribed (IVT) mRNA. However, compared to research-grade mRNA, manufacture, and final release of IVT mRNA for clinical use in humans usually requires more quality controls (QC). These controls include the quantification of the mRNA concentration, purity, and integrity, but also the confirmation of the identity the mRNA, its sterility, its potency, and the absence of potentially damaging endotoxins. 


\section{Clinical Application of mRNA Electroporation in Cell-Based Immunotherapies}

Electroporation of mRNA as a pharmaceutical tool for transient expression of proteins of interest has been applied as a therapeutic strategy in malignant, infectious, and autoimmune diseases. Loading antigen-presenting dendritic cells (DCs) with tumor-associated antigens (TAAs) alone or in combination with immune-modulating molecules, such as agonists of T-cell activation, is the most common usage of mRNA electroporation in a clinical setting (Table 1). This therapeutic modality focuses on promoting multi-epitope antigen-specific T-cell responses to target tumor cells. Taking this idea further, multiple mRNA encoding different TAAs can be co-electroporated in order to improve immune responses and to avoid immune evasion. Another application, as a safer and more versatile alternative than viral transduction, is the redirection of $\mathrm{T}$ cells with immune receptors such as T-cell receptors (TCRs) and chimeric antigen receptors (CARs) to specifically and directly target TAAs presented by tumor cells (Table 2). Although less popular compared to $\mathrm{T}$ cells in a clinical context, peripheral blood mononuclear cells and natural killer cells can also be engineered to express such immune receptors in a transient way, with only a few trials evaluating the former for the treatment of ovarian cancer and malignant peritoneal mesothelioma (NCT03608618; [59]) and the latter for the treatment of colorectal cancer (NCT03415100; Table 3).

The use of mRNA electroporation for the treatment of infectious diseases has been less widespread compared to solid and hematological malignancies. DCs have been engineered with human immunodeficiency virus (HIV) antigens alone or in combination with immunemodulating molecules for the treatment of HIV infection (Table 1). Furthermore, mRNA electroporation has been used to introduce zinc finger nucleases for the disruption of CCR5, a key chemokine receptor in HIV infection, in CD4 T cells to protect the adoptivelytransferred CCR5-edited CD4 T cells from HIV targeting (NCT02388594, Table 2). Only one registered clinical study relies on this technique to redirect T-cell specificity in type 1 diabetes (NCT02117518, Table 2). In preparation for clinical translation, tolerogenic DCs electroporated with mRNA-encoding myelin antigens have shown promising results in mouse models for the treatment of multiple sclerosis [60], warranting the exploration of these findings in clinical trials. 
Table 1. mRNA synthesis and electroporation conditions in clinical trials using mRNA electroporation for gene transfer in dendritic cells.

\begin{tabular}{|c|c|c|c|c|c|c|}
\hline \multirow{2}{*}{ Disease } & \multirow{2}{*}{ Gene(s) } & \multicolumn{2}{|c|}{ mRNA Synthesis } & \multicolumn{2}{|c|}{ EP Conditions } & \multirow{2}{*}{$\begin{array}{c}\text { Clinical Trial Identifier } \\
\text { and } \\
\text { References }\end{array}$} \\
\hline & & Template & Production & Device & Settings & \\
\hline \multicolumn{7}{|c|}{ Solid malignancies } \\
\hline Melanoma & $\begin{array}{c}\text { TAA } \\
\text { (murine TRP2) }\end{array}$ & Linearized pING vector & mMessage mMachine T7 kit & $\begin{array}{c}\text { BTX ECM } 830 \text { square wave } \\
\text { electroporator }\end{array}$ & $\begin{array}{l}700 \mathrm{~V} \text { (two pulses) } \\
\text { 2-mm cuvette }\end{array}$ & $\begin{array}{c}\text { NCT01456104 } \\
{[61]}\end{array}$ \\
\hline Melanoma & $\begin{array}{c}\text { TAA } \\
\text { (gp100, tyrosinase) }\end{array}$ & $\begin{array}{c}\text { Linearized } \\
\text { pGEM4Z/hgp100/A64 } \\
\text { pGEM4Z/tyrosinase/A64 } \\
\text { vectors } \\
\end{array}$ & $\begin{array}{l}\text { Produced by CureVac GmbH } \\
\text { Purified by PUREmessenger } \\
\text { (chromatography) }\end{array}$ & Gene Pulser Xcell (Bio-Rad) & $\begin{array}{c}\text { Exponential decay pulse } \\
(300 \mathrm{~V}, 150 \mu \mathrm{F}) \\
4-\mathrm{mm} \text { cuvette }\end{array}$ & $\begin{array}{c}\text { NCT00243529 } \\
{[62]}\end{array}$ \\
\hline Melanoma & $\begin{array}{c}\text { TAA } \\
\text { (h-TERT, survivin) + tumor } \\
\text { cell mRNA }\end{array}$ & ND & $\begin{array}{c}\text { T7 mMESSAGE mMACHINE } \\
\text { large-scale transcription kit } \\
\text { (Ambion) } \\
\text { Purified with MEGAclear } \\
\text { column (Ambion) }\end{array}$ & $\begin{array}{l}\text { BTX ECM } 830 \text { square wave } \\
\text { electroporator }\end{array}$ & Square wave pulse & $\begin{array}{c}\text { NCT00961844 } \\
\text { [63-65] }\end{array}$ \\
\hline Melanoma & $\begin{array}{c}\text { TAA } \\
\text { (gp100 and tyrosinase) }+ \\
\text { immune modulating } \\
\text { molecules (active TLR4, } \\
\text { CD70) }\end{array}$ & $\begin{array}{c}\text { Linearized } \\
\text { pGEM4Z/hgp100/A64 } \\
\text { pGEM4Z/tyrosinase/A64 } \\
\text { vectors }\end{array}$ & $\begin{array}{l}\text { Produced by CureVac GmbH } \\
\text { Purified by PUREmessenger } \\
\text { technology (chromatography) }\end{array}$ & Gene Pulser Xcell (Bio-Rad) & $\begin{array}{c}\text { Exponential decay pulse } \\
(300 \mathrm{~V}, 150 \mu \mathrm{F}) \\
4-\mathrm{mm} \text { cuvette }\end{array}$ & $\begin{array}{c}\text { NCT01530698 } \\
\text { NCT00940004 } \\
{[62,66]}\end{array}$ \\
\hline $\begin{array}{l}\text { Breast cancer } \\
\text { Melanoma }\end{array}$ & $\begin{array}{c}\text { TAA } \\
\text { (hTERT, survivin, p53) }\end{array}$ & $\begin{array}{c}\text { Linearized pCI/hTERT/A102 } \\
\text { pSP73/p53/A64 } \\
\text { pSP73/survivin/A64 } \\
\text { vectors }\end{array}$ & $\begin{array}{c}\text { mMESSAGE mMACHINE T7 } \\
\text { Ultra kit (Life Technologies) } \\
\text { Purified with MEGAclear kit } \\
\text { (Ambion) } \\
\text { Length, concentration, and } \\
\text { purity evaluated with Agilent } \\
\text { 2100 Bioanalyzer (Agilent } \\
\text { Technologies) using RNA } 6000 \\
\text { Nano LabChip Kit (Agilent } \\
\text { Technologies) }\end{array}$ & $\begin{array}{l}\text { BTX ECM } 830 \text { square wave } \\
\text { electroporator }\end{array}$ & $\begin{array}{l}\text { Square wave pulse (500 V, } 2 \\
\text { ms) } \\
\text { 4-mm cuvette (placed for } 5 \\
\text { min on ice) }\end{array}$ & $\begin{array}{c}\text { NCT00978913 } \\
{[70]}\end{array}$ \\
\hline
\end{tabular}


Table 1. Cont.

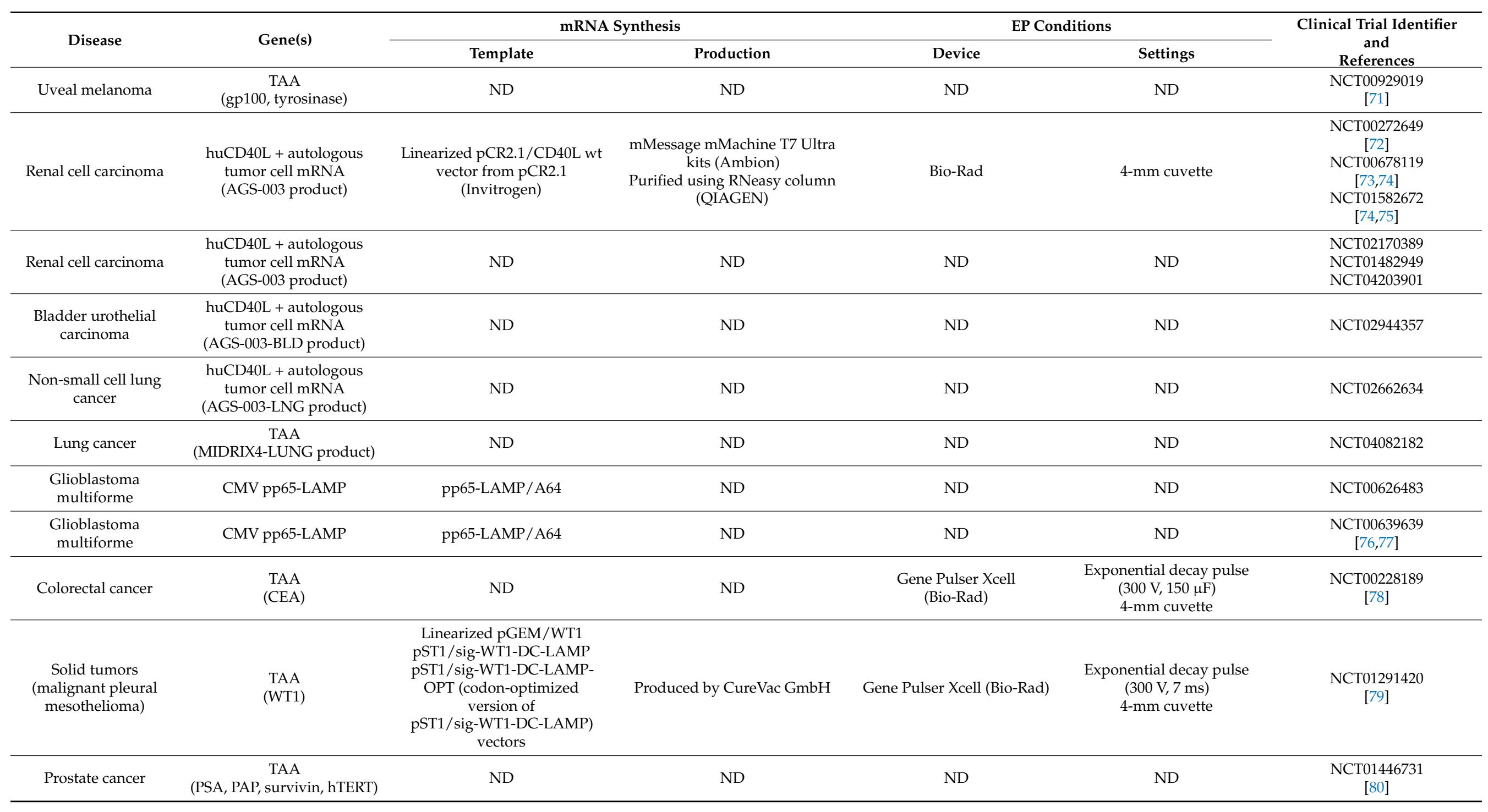


Table 1. Cont.

\begin{tabular}{|c|c|c|c|c|c|c|}
\hline \multirow{2}{*}{ Disease } & \multirow{2}{*}{ Gene(s) } & \multicolumn{2}{|c|}{ mRNA Synthesis } & \multicolumn{2}{|c|}{ EP Conditions } & \multirow{2}{*}{$\begin{array}{c}\text { Clinical Trial Identifier } \\
\text { and } \\
\text { References }\end{array}$} \\
\hline & & Template & Production & Device & Settings & \\
\hline \multicolumn{7}{|c|}{ Hematological malignancies } \\
\hline $\begin{array}{l}\text { Hematological } \\
\text { malignancies }\end{array}$ & TAA & ND & ND & ND & ND & NCT02528682 \\
\hline $\begin{array}{l}\text { Acute myeloid } \\
\text { leukemia }\end{array}$ & TAA & ND & ND & ND & ND & NCT01686334 \\
\hline $\begin{array}{l}\text { Acute myeloid } \\
\text { leukemia }\end{array}$ & $\begin{array}{c}\text { TAA } \\
\text { (WT1) }\end{array}$ & ND & Produced by CureVac $\mathrm{GmbH}$ & Gene Pulser Xcell (Bio-Rad) & $\begin{array}{c}\text { Exponential decay pulse } \\
(300 \mathrm{~V}, 7 \mathrm{~ms}) \\
4-\mathrm{mm} \text { cuvette }\end{array}$ & $\begin{array}{c}\text { NCT00834002 } \\
{[81]}\end{array}$ \\
\hline $\begin{array}{l}\text { Acute myeloid } \\
\text { leukemia } \\
\text { Chronic myeloid } \\
\text { leukemia } \\
\text { Multiple myeloma }\end{array}$ & $\begin{array}{c}\text { TAA } \\
\text { (WT1) }\end{array}$ & $\begin{array}{l}\text { Linearized pGEM/WT1 } \\
\text { pST1/sig-WT1-DC-LAMP } \\
\text { pST1/sig-WT1-DC-LAMP- } \\
\text { OPT (codon-optimized } \\
\text { version of } \\
\text { pST1/sig-WT1-DC-LAMP) } \\
\text { vectors }\end{array}$ & Produced by CureVac GmbH & Gene Pulser Xcell (Bio-Rad) & $\begin{array}{c}\text { Exponential decay pulse } \\
(300 \mathrm{~V}, 7 \mathrm{~ms}) \\
4 \text {-mm cuvette }\end{array}$ & $\begin{array}{c}\text { NCT00965224 } \\
{[82]}\end{array}$ \\
\hline $\begin{array}{l}\text { Acute myeloid } \\
\text { leukemia }\end{array}$ & $\begin{array}{c}\text { TAA } \\
\text { (hTERT-LAMP-1) }\end{array}$ & $\begin{array}{l}\text { Linearized } \\
\text { pGEM4Z/hTERT/LAMP/A64 } \\
\text { vector }\end{array}$ & $\begin{array}{c}\text { mMESSAGE mMACHINE high } \\
\text { yield capped RNA transcription } \\
\text { kit (Ambion) } \\
\text { Purified with RNeasy kit } \\
\text { (Qiagen) }\end{array}$ & Gene Pulser II (Bio-Rad) & $\begin{array}{c}\text { Cells + mRNA for } 5 \text { min on } \\
\text { ice } \\
\text { Exponential decay pulse } \\
(300 \mathrm{~V}, 150 \mu \mathrm{F}) \\
4-\mathrm{mm} \text { cuvette }\end{array}$ & $\begin{array}{c}\text { NCT00510133 } \\
{[83,84]}\end{array}$ \\
\hline $\begin{array}{l}\text { Acute myeloid } \\
\text { leukemia }\end{array}$ & $\begin{array}{c}\text { TAA } \\
\text { (WT1 isoform A, PRAME, } \\
\text { CMV pp65) }\end{array}$ & Codon-optimized mRNA & $\begin{array}{c}\text { Produced at Oslo University } \\
\text { Hospital }\end{array}$ & ND & ND & $\begin{array}{c}\text { NCT01734304 } \\
\text { [85-87] }\end{array}$ \\
\hline $\begin{array}{l}\text { Myelodysplastic } \\
\text { syndromes } \\
\text { Acute myeloid } \\
\text { leukemia }\end{array}$ & TAA & ND & ND & ND & ND & NCT03083054 \\
\hline Multiple myeloma & TAA & ND & ND & ND & ND & NCT01995708 \\
\hline
\end{tabular}


Table 1. Cont.

\begin{tabular}{|c|c|c|c|c|c|c|}
\hline \multirow{2}{*}{ Disease } & \multirow{2}{*}{ Gene(s) } & \multicolumn{2}{|c|}{ mRNA Synthesis } & \multicolumn{2}{|c|}{ EP Conditions } & \multirow{2}{*}{$\begin{array}{c}\text { Clinical Trial Identifier } \\
\text { and } \\
\text { References }\end{array}$} \\
\hline & & Template & Production & Device & Settings & \\
\hline \multicolumn{7}{|c|}{ Infectious diseases } \\
\hline HIV & $\begin{array}{l}\text { HIV antigen (Gag, Nef, Vpr, } \\
\text { Rev (GNVR)) + immune } \\
\text { modulating molecules } \\
\text { (hCD40L) (AGS-004 } \\
\text { product) }\end{array}$ & $\begin{array}{l}\text { HIV antigens: PCR fragments } \\
\text { hCD40L: Linearized pCR2.1 } \\
\text { vector }\end{array}$ & $\begin{array}{l}\text { mMessage mMachine T7 Ultra } \\
\text { kit (Life Technologies) } \\
\text { Purified with RNeasy columns } \\
\text { (QIAGEN) }\end{array}$ & ND & ND & $\begin{array}{c}\text { NCT02042248 } \\
{[88,89]} \\
\text { NCT02707900 } \\
{[90]} \\
\text { NCT00381212 } \\
{[91]} \\
\text { NCT01069809 } \\
\text { NCT00672191 } \\
{[92]}\end{array}$ \\
\hline HIV & $\begin{array}{l}\text { HIV antigen (HIV-1 Gag, } \\
\text { Nef) }\end{array}$ & $\begin{array}{l}\text { Codon-optimized coding } \\
\text { sequence including } \\
\text { endoplasmic reticulum } \\
\text { translocation signal peptide, } \\
\text { antigen polypeptide, and } \\
\text { human lysosome-associated } \\
\text { membrane protein-1 targeting } \\
\text { sequence }\end{array}$ & Produced by Asuragen & Gene Pulser II (Bio-Rad) & $\begin{array}{c}\text { Square wave pulse }(900 \mathrm{~V}, \\
0.75 \mathrm{~ms})\end{array}$ & $\begin{array}{c}\text { NCT00833781 } \\
{[93]}\end{array}$ \\
\hline CMV & CMV pp65 & ND & Produced by Curevac $\mathrm{GmbH}$ & ND & ND & $\begin{array}{c}\text { EudraCT 2008-006074-15 } \\
\text { EudraCT 2008-000430-45 } \\
\text { [95] }\end{array}$ \\
\hline
\end{tabular}

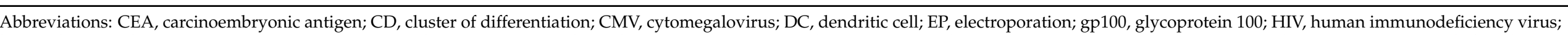

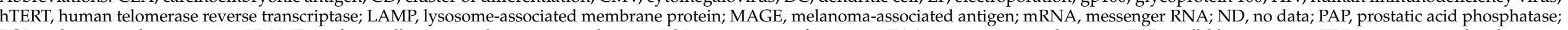

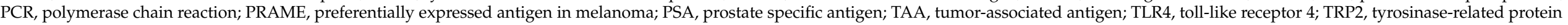
2; WT1, Wilms' tumor 1. Last search on clinicaltrials.gov and PubMed: 5 March 2021. 
Table 2. mRNA synthesis and electroporation conditions in clinical trials using mRNA electroporation for gene transfer in T cells.

\begin{tabular}{|c|c|c|c|c|c|c|}
\hline \multirow{2}{*}{ Condition } & \multirow{2}{*}{ Gene } & \multicolumn{2}{|c|}{ mRNA Synthesis } & \multicolumn{2}{|c|}{ EP Conditions } & \multirow{2}{*}{$\begin{array}{c}\text { Clinical Trial } \\
\text { Identifier and } \\
\text { References }\end{array}$} \\
\hline & & Template & Production & Device & Settings & \\
\hline \multicolumn{7}{|c|}{ Solid malignancies } \\
\hline $\begin{array}{l}\text { Malignant peritoneal } \\
\text { mesothelioma }\end{array}$ & CAR & $\begin{array}{c}\text { Linearized pDrive vector } \\
\text { (Qiagen) } \\
\text { (GOI + two repeats of } \\
\text { 3'-UTR from beta globulin } \\
\text { (2bgUTR) with or without } \\
150 \text { poly(A) tail) }\end{array}$ & $\begin{array}{c}\text { mMESSAGE mMACHINE T7 kit } \\
\text { (including regular cap analog; Life } \\
\text { Technologies) } \\
\text { mMESSAGE mMACHINE T7 Ultra } \\
\text { kit (including anti-reverse cap } \\
\text { analog; Life Technologies) } \\
\text { mScript }^{\mathrm{TM}} \text { RNA System (including } \\
\text { capping enzyme and } \\
\text { 2'-O-Methyltransferase capping }^{\text {'-Onze }} \text { enzyme to generate Cap 1 IVT RNA; } \\
\text { Epicentre) }\end{array}$ & $\begin{array}{c}\text { BTX ECM } 830 \text { square } \\
\text { wave electropora- } \\
\text { tor/Maxcyte }\end{array}$ & $\begin{array}{l}\text { 2-mm cuvette (BTX) } \\
\text { /OC-400 (Maxcyte) }\end{array}$ & $\begin{array}{c}\text { NCT01355965 } \\
{[96-98]}\end{array}$ \\
\hline $\begin{array}{l}\text { Pancreatic ductal } \\
\text { adenocarcinoma } \\
\text { Breast cancer }\end{array}$ & CAR & $\begin{array}{c}\text { Linearized pDrive vector } \\
\text { (Qiagen) } \\
\text { (GOI + two repeats of } \\
\text { 3'-UTR from beta globulin } \\
\text { (2bgUTR) with or without } \\
150 \text { poly(A) tail) }\end{array}$ & $\begin{array}{c}\text { mMESSAGE mMACHINE T7 kit } \\
\text { (including regular cap analog; Life } \\
\text { Technologies) } \\
\text { mMESSAGE mMACHINE T7 Ultra } \\
\text { kit (including anti-reverse cap } \\
\text { analog; Life Technologies) } \\
\text { mScript }^{\mathrm{TM}} \text { RNA System (including } \\
\text { capping enzyme and } \\
\text { 2'-O-Methyltransferase capping }^{\text {'-Onze }} \text { enzyme to generate Cap 1 IVT RNA; } \\
\text { Epicentre) }\end{array}$ & Maxcyte & ND & $\begin{array}{c}\text { NCT01897415 [98-100] } \\
\text { NCT01837602 } \\
{[98-101]}\end{array}$ \\
\hline Breast cancer & CAR & ND & ND & ND & ND & $\begin{array}{c}\text { NCT03060356 } \\
\text { [102] }\end{array}$ \\
\hline
\end{tabular}


Table 2. Cont.

\begin{tabular}{|c|c|c|c|c|c|c|}
\hline \multirow{2}{*}{ Condition } & \multirow{2}{*}{ Gene } & \multicolumn{2}{|c|}{ mRNA Synthesis } & \multicolumn{2}{|c|}{ EP Conditions } & \multirow{2}{*}{$\begin{array}{c}\text { Clinical Trial } \\
\text { Identifier and } \\
\text { References }\end{array}$} \\
\hline & & Template & Production & Device & Settings & \\
\hline $\begin{array}{l}\text { Hepatocellular } \\
\text { carcinoma }\end{array}$ & TCR & Linearized pVAX1 vector & $\begin{array}{c}\text { mMESSAGE mMACHINE T7 Ultra } \\
\text { kit (including anti-reverse cap } \\
\text { analog; Life Technologies) } \\
\text { Concentrated by lithium chloride } \\
\text { precipitation } \\
\text { Dissolved in T4 buffer (BTX) }\end{array}$ & $\begin{array}{l}\text { AgilePulse Max } \\
\text { system (BTX) }\end{array}$ & $\begin{array}{l}\text { Manufacturer's } \\
\text { recommended protocol }\end{array}$ & $\begin{array}{l}\text { NCT02719782 } \\
{[103-105]} \\
\text { NCT03634683 } \\
{[103,104]} \\
\text { NCT03899415 } \\
{[103,104,106]}\end{array}$ \\
\hline Colorectal cancer & TCR & $\begin{array}{c}\text { mRNA expression vector } \\
\text { Sequence containing } 2 \mathrm{~A} \\
\text { construct }\end{array}$ & $\begin{array}{l}\text { Capping: Anti-Reverse Cap Analog } \\
\text { (TriLink Biotechnologies Inc.) }\end{array}$ & $\begin{array}{l}\text { BTX ECM } 830 \text { square } \\
\text { wave electroporator }\end{array}$ & $\begin{array}{l}\text { Square Wave pulse } \\
\text { (500 V, } 2 \mathrm{~ms}) \\
\text { 4-mm cuvette }\end{array}$ & $\begin{array}{c}\text { NCT03431311 } \\
{[107,108]}\end{array}$ \\
\hline \multicolumn{7}{|c|}{ Hematological malignancies } \\
\hline Hodgkin lymphoma & CAR & $\begin{array}{l}\text { Linearized pGEM4-Z/A64 } \\
\text { vector }\end{array}$ & $\begin{array}{l}\text { mMESSAGE mMACHINE T7 Ultra } \\
\text { kit (including anti-reverse cap } \\
\text { analog and in vitro poly(A) tailing } \\
\text { ("E-PAP"); Life Technologies) }\end{array}$ & $\begin{array}{l}\text { Gene Pulser Xcell } \\
\text { (BioRad) }\end{array}$ & $\begin{array}{l}\text { Square wave pulse } \\
\quad(500 \mathrm{~V}, 5 \mathrm{~ms})\end{array}$ & $\begin{array}{l}\text { NCT02277522 } \\
\text { NCT02624258 } \\
\quad[109-111]\end{array}$ \\
\hline $\begin{array}{l}\text { B-cell non-Hodgkin's } \\
\text { lymphoma } \\
\text { B-cell chronic } \\
\text { lymphocytic leukemia }\end{array}$ & CAR & ND & ND & ND & ND & $\begin{array}{c}\text { NCT02315118 } \\
\text { [112] }\end{array}$ \\
\hline Acute myeloid leukemia & CAR & Linearized pDA vector & $\begin{array}{l}\text { mMESSAGE mMACHINE T7 Ultra } \\
\text { kit (including anti-reverse cap } \\
\text { analog; Life Technologies) } \\
\text { mRNA purified by RNeasy Mini Kit } \\
\text { (Qiagen) }\end{array}$ & $\begin{array}{l}\text { BTX ECM } 830 \text { square } \\
\text { wave electroporator }\end{array}$ & 2-mm cuvette & $\begin{array}{l}\text { NCT02623582 } \\
\text { [113-115] }\end{array}$ \\
\hline
\end{tabular}


Table 2. Cont.

\begin{tabular}{|c|c|c|c|c|c|c|}
\hline \multirow{2}{*}{ Condition } & \multirow{2}{*}{ Gene } & \multicolumn{2}{|c|}{ mRNA Synthesis } & \multicolumn{2}{|c|}{ EP Conditions } & \multirow{2}{*}{$\begin{array}{c}\text { Clinical Trial } \\
\text { Identifier and } \\
\text { References }\end{array}$} \\
\hline & & Template & Production & Device & Settings & \\
\hline Multiple myeloma & CAR & $\begin{array}{l}\text { Linearized DNA plasmid } \\
\text { Codon-optimized } \\
\text { nucleotide sequence } \\
\text { containing } 3^{\prime}-\text {-UTR, mouse } \\
\text { alpha globin } 5^{\prime} \text {-UTR, and } \\
\text { poly(A) tail }\end{array}$ & ND & ND & ND & $\begin{array}{c}\text { NCT03448978 } \\
{[116,117]}\end{array}$ \\
\hline
\end{tabular}

Autoimmune diseases

CD3-zeta

ND

ND

ND

NCT02117518

\section{Infectious diseases}

$\begin{array}{cc}\text { Linearized } \\ \text { HIV } & \text { ZFN }\end{array}$
mMESSAGE mMACHINE T7 Ultra
Transfection System

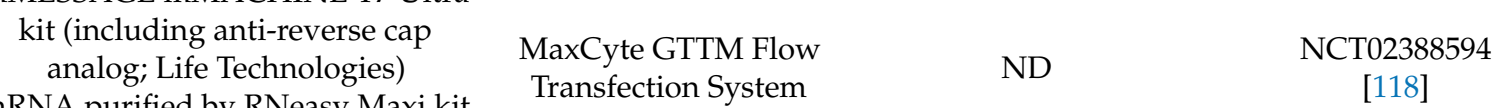

vector

[118]

$$
\text { (Qiagen) }
$$

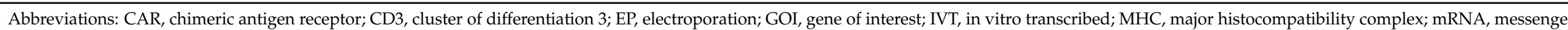
RNA; ND, no data; TCR, T-cell receptor; UTR, untranslated region; ZFN, zinc finger nuclease. Last search on clinicaltrials.gov and PubMed: 5 March 2021.

Table 3. mRNA synthesis and electroporation conditions in clinical trials using mRNA electroporation for gene transfer in natural killer cells.

\begin{tabular}{|c|c|c|c|c|c|c|}
\hline \multirow{2}{*}{ Condition } & \multirow{2}{*}{ Gene } & \multicolumn{2}{|c|}{ mRNA Synthesis } & \multicolumn{2}{|c|}{ EP Conditions } & \multirow{2}{*}{$\begin{array}{c}\text { Clinical Trial Identifier } \\
\text { and Reference }\end{array}$} \\
\hline & & Template & Production & Device & Settings & \\
\hline Colorectal cancer & CAR & $\begin{array}{l}\text { PCR product from pFBCMV-T7 vector } \\
\text { GOI + 5'-UTR with Kozak sequence, } \\
\text { and } \\
\text { ClaI, the GM-CSF signal peptide } \\
\text { encoding sequence (SP) and the } \\
\text { alpha-globin } 3^{\prime} \text {-UTR sequence }\end{array}$ & $\begin{array}{c}\text { mMESSAGE mMACHINE T7 } \\
\text { Ultra kit (including } \\
\text { anti-reverse cap analog } \\
\text { (ARCA); Life Technologies) } \\
\text { mScript }{ }^{\mathrm{TM}} \text { RNA system } \\
\text { (Epicentre) }\end{array}$ & $\begin{array}{c}\text { NEPA21 electroporator } \\
\text { (Nepagene) } \\
\text { BTX electroporator } \\
\text { (AgilePulse) }\end{array}$ & 2 or 4 -mm cuvette & $\begin{array}{c}\text { NCT03415100 } \\
\text { [119] }\end{array}$ \\
\hline
\end{tabular}

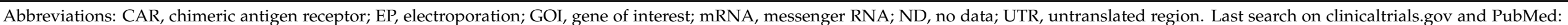
5 March 2021. 


\section{Conclusions}

Electroporation of mRNA is a versatile methodology for the transient expression of proteins of interest. As a highly flexible system, it allows the fine-tuning of transfection conditions for each cell type and to multiplex mRNAs as required. The selection of the best transfection conditions for mRNA ensures maximal transfection efficiency, and thus protein expression, without compromising cell viability. As we have noted, there is a wide variety of options when it comes to improving both the electroporation conditions and stability / translation of the mRNAs for monocistronic and polycistronic gene transfer. These enhancements and different tools can be used either alone or in combination, depending on the needs of the study. Although we have focused on conventional mRNA, similar statements are true for other types of RNA, such as small interfering RNA, guide RNA in a CRISPR setting, or non-conventional self-replicating mRNA but also for purposes other than the transient gene transfer, as in gene silencing and gene disruption. The safety of the system due to its transient non-integrative approach together with its simplicity in terms of the basic equipment needed for its application ensure that mRNA electroporation will continue to be an essential method for non-viral genetic engineering in cell-based immunotherapies, especially in a clinical setting.

Author Contributions: Conceptualization, D.C.-D.; writing—original draft preparation, D.C.-D. and M.D.L.; writing—review and editing, G.R., M.V., D.F., Z.N.B., V.F.I.V.T., S.A. and E.L; visualization, D.C.-D.; supervision, E.L. All authors have read and agreed to the published version of the manuscript.

Funding: This research was supported by a "Cellular Immunotherapy" grant from the vzw Baillet Latour Fund (Belgium), and the Cellular Therapy Fund from the Antwerp University Hospital (UZA) Foundation. D.C.D. was supported by a DOC-PRO PhD grant from the Special Research Fund (BOF) of the University of Antwerp and by grant G053518N from the Research Foundation-Flanders (FWO, Belgium). M.D.L. was supported by funds from FWO (grant T001216N) and Stichting tegen Kanker (STK, Belgium; grant FAF-C/2018/1211). G.R. was supported by a Doctoral Grant Strategic Basic Research of the FWO (grant 1S72821N), an Emmanuel van der Schueren fellowship from Kom op tegen Kanker (KotK, Belgium), and the Public Utility Foundation Stichting ME TO YOU (Belgium). M.V. was supported by an SB-fellowship from the FWO (grant 1S24517N). D.F. was supported by a "Cellular Immunotherapy" grant from the vzw Baillet Latour Fund. S.A. is a senior clinical investigator of the FWO (grant 1806220N). E.L. was supported by funds from FWO (grant T001216N) and KotK (grant KotK/2018/11465/). V.F.I.V.T. and Z.N.B. are inventors of a US patent \#7547551 licensed to CiMAAS BV, The Netherlands and to Argos Therapeutics USA.

Institutional Review Board Statement: Not applicable.

Informed Consent Statement: Not applicable.

Data Availability Statement: Data sharing not applicable.

Conflicts of Interest: The authors declare no conflict of interest.

\section{References}

1. Rolong, A.; Davalos, R.V.; Rubinsky, B. History of Electroporation. In Irreversible Electroporation in Clinical Practice; Meijerink, M.R., Scheffer, H.J., Narayanan, G., Eds.; Springer International Publishing: Cham, Switzerland, 2018; pp. 13-37. [CrossRef]

2. Stampfli, R.; Willi, M. Membrane potential of a Ranvier node measured after electrical destruction of its membrane. Experientia 1957, 13, 297-298. [CrossRef] [PubMed]

3. Neumann, E.; Schaefer-Ridder, M.; Wang, Y.; Hofschneider, P.H. Gene transfer into mouse lyoma cells by electroporation in high electric fields. EMBO J. 1982, 1, 841-845. [CrossRef] [PubMed]

4. Dullaers, M.; Breckpot, K.; Van Meirvenne, S.; Bonehill, A.; Tuyaerts, S.; Michiels, A.; Straetman, L.; Heirman, C.; De Greef, C.; Van Der Bruggen, P.; et al. Side-by-side comparison of lentivirally transduced and mRNA-electroporated dendritic cells: Implications for cancer immunotherapy protocols. Mol. Ther. 2004, 10, 768-779. [CrossRef]

5. Devoldere, J.; Dewitte, H.; De Smedt, S.C.; Remaut, K. Evading innate immunity in nonviral mRNA delivery: don't shoot the messenger. Drug Discov. Today 2016, 21, 11-25. [CrossRef] 
6. Van Tendeloo, V.F.; Ponsaerts, P.; Lardon, F.; Nijs, G.; Lenjou, M.; Van Broeckhoven, C.; Van Bockstaele, D.R.; Berneman, Z.N. Highly efficient gene delivery by mRNA electroporation in human hematopoietic cells: Superiority to lipofection and passive pulsing of mRNA and to electroporation of plasmid cDNA for tumor antigen loading of dendritic cells. Blood 2001, 98, 49-56. [CrossRef]

7. Smits, E.; Ponsaerts, P.; Lenjou, M.; Nijs, G.; Van Bockstaele, D.R.; Berneman, Z.N.; Van Tendeloo, V.F. RNA-based gene transfer for adult stem cells and T cells. Leukemia 2004, 18, 1898-1902. [CrossRef]

8. Gehl, J. Electroporation: Theory and methods, perspectives for drug delivery, gene therapy and research. Acta Physiol. Scand. 2003, 177, 437-447. [CrossRef]

9. Chang, D. Electroporation and Electrofusion. Rev. Cell Biol. Mol. Med. 2006, 2, 198-206.

10. Luft, C.; Ketteler, R. Electroporation Knows no Boundaries: The Use of Electrostimulation for siRNA Delivery in Cells and Tissues. J. Biomol. Screen. 2015, 20, 932-942. [CrossRef]

11. Rosazza, C.; Meglic, S.H.; Zumbusch, A.; Rols, M.P.; Miklavcic, D. Gene Electrotransfer: A Mechanistic Perspective. Curr. Gene Ther. 2016, 16, 98-129. [CrossRef]

12. Heiser, W.C. Optimizing electroporation conditions for the transformation of mammalian cells. Methods Mol. Biol. 2000, 130, 117-134. [CrossRef]

13. Weaver, J.C.; Smith, K.C.; Esser, A.T.; Son, R.S.; Gowrishankar, T.R. A brief overview of electroporation pulse strength-duration space: A region where additional intracellular effects are expected. Bioelectrochemistry 2012, 87, 236-243. [CrossRef]

14. Teissié, J. Cell Membrane Electropermeabilization. In Bioelectrochemistry of Membranes; Walz, D., Teissié, J., Milazzo, G., Eds.; Birkhäuser Basel: Basel, Switzerland, 2004; pp. 205-235. [CrossRef]

15. Sherba, J.J.; Hogquist, S.; Lin, H.; Shan, J.W.; Shreiber, D.I.; Zahn, J.D. The effects of electroporation buffer composition on cell viability and electro-transfection efficiency. Sci. Rep. 2020, 10, 3053. [CrossRef]

16. Silve, A.; Leray, I.; Poignard, C.; Mir, L.M. Impact of external medium conductivity on cell membrane electropermeabilization by microsecond and nanosecond electric pulses. Sci. Rep. 2016, 6, 19957. [CrossRef]

17. Pucihar, G.; Kotnik, T.; Kanduser, M.; Miklavcic, D. The influence of medium conductivity on electropermeabilization and survival of cells in vitro. Bioelectrochemistry 2001, 54, 107-115. [CrossRef]

18. Schlaak, C.; Hoffmann, P.; May, K.; Weimann, A. Desalting minimal amounts of DNA for electroporation in E. coli: A comparison of different physical methods. Biotechnol. Lett. 2005, 27, 1003-1005. [CrossRef]

19. Bahnson, A.B.; Boggs, S.S. Addition of serum to electroporated cells enhances survival and transfection efficiency. Biochem. Biophys. Res. Commun. 1990, 171, 752-757. [CrossRef]

20. Welter, J.F.; Solchaga, L.A.; Stewart, M.C. High-efficiency nonviral transfection of primary chondrocytes. Methods Mol. Med. 2004, 100, 129-146. [CrossRef]

21. Jordan, E.T.; Collins, M.; Terefe, J.; Ugozzoli, L.; Rubio, T. Optimizing electroporation conditions in primary and other difficult-totransfect cells. J. Biomol. Tech. 2008, 19, 328-334.

22. Ramanathan, A.; Robb, G.B.; Chan, S.H. mRNA capping: Biological functions and applications. Nucleic Acids Res. 2016, 44, 7511-7526. [CrossRef]

23. Shi, Y.; Manley, J.L. The end of the message: Multiple protein-RNA interactions define the mRNA polyadenylation site. Genes Dev. 2015, 29, 889-897. [CrossRef]

24. Moore, M.J. From birth to death: The complex lives of eukaryotic mRNAs. Science 2005, 309, 1514-1518. [CrossRef]

25. Kuhn, U.; Gundel, M.; Knoth, A.; Kerwitz, Y.; Rudel, S.; Wahle, E. Poly(A) tail length is controlled by the nuclear poly(A)-binding protein regulating the interaction between poly(A) polymerase and the cleavage and polyadenylation specificity factor. J. Biol. Chem. 2009, 284, 22803-22814. [CrossRef]

26. Wiederhold, K.; Passmore, L.A. Cytoplasmic deadenylation: Regulation of mRNA fate. Biochem. Soc. Trans. 2010, 38, 1531-1536. [CrossRef]

27. Weill, L.; Belloc, E.; Bava, F.A.; Mendez, R. Translational control by changes in poly(A) tail length: Recycling mRNAs. Nat. Struct. Mol. Biol. 2012, 19, 577-585. [CrossRef]

28. Russell, J.E.; Liebhaber, S.A. The stability of human beta-globin mRNA is dependent on structural determinants positioned within its $3^{\prime}$ untranslated region. Blood 1996, 87, 5314-5323. [CrossRef]

29. Holtkamp, S.; Kreiter, S.; Selmi, A.; Simon, P.; Koslowski, M.; Huber, C.; Tureci, O.; Sahin, U. Modification of antigen-encoding RNA increases stability, translational efficacy, and T-cell stimulatory capacity of dendritic cells. Blood 2006, 108, 4009-4017. [CrossRef] [PubMed]

30. Ferizi, M.; Aneja, M.K.; Balmayor, E.R.; Badieyan, Z.S.; Mykhaylyk, O.; Rudolph, C.; Plank, C. Human cellular CYBA UTR sequences increase mRNA translation without affecting the half-life of recombinant RNA transcripts. Sci. Rep. 2016, 6, 39149. [CrossRef] [PubMed]

31. Kozak, M. An analysis of 5'-noncoding sequences from 699 vertebrate messenger RNAs. Nucleic Acids Res. 1987, 15, 8125-8148. [CrossRef]

32. Yisraeli, J.K.; Melton, D.A. Synthesis of long, capped transcripts in vitro by SP6 and T7 RNA polymerases. Methods Enzym. 1989, 180, 42-50.

33. Krieg, P.A.; Melton, D.A. Functional messenger RNAs are produced by SP6 in vitro transcription of cloned cDNAs. Nucleic Acids Res. 1984, 12, 7057-7070. [CrossRef] [PubMed] 
34. Milligan, J.F.; Groebe, D.R.; Witherell, G.W.; Uhlenbeck, O.C. Oligoribonucleotide synthesis using T7 RNA polymerase and synthetic DNA templates. Nucleic Acids Res. 1987, 15, 8783-8798. [CrossRef]

35. Gurevich, V.V.; Pokrovskaya, I.D.; Obukhova, T.A.; Zozulya, S.A. Preparative in vitro mRNA synthesis using SP6 and T7 RNA polymerases. Anal. Biochem. 1991, 195, 207-213. [CrossRef]

36. Kozak, M. Pushing the limits of the scanning mechanism for initiation of translation. Gene 2002, 299, 1-34. [CrossRef]

37. Brunelle, J.L.; Green, R. In vitro transcription from plasmid or PCR-amplified DNA. Methods Enzym. 2013, 530, 101-114. [CrossRef]

38. Avci-Adali, M.; Behring, A.; Steinle, H.; Keller, T.; Krajeweski, S.; Schlensak, C.; Wendel, H.P. In vitro synthesis of modified mRNA for induction of protein expression in human cells. J. Vis. Exp. 2014, e51943. [CrossRef]

39. Muttach, F.; Muthmann, N.; Rentmeister, A. Synthetic mRNA capping. Beilstein J. Org. Chem. 2017, 13, 2819-2832. [CrossRef]

40. Grier, A.E.; Burleigh, S.; Sahni, J.; Clough, C.A.; Cardot, V.; Choe, D.C.; Krutein, M.C.; Rawlings, D.J.; Jensen, M.C.; Scharenberg, A.M.; et al. pEVL: A Linear Plasmid for Generating mRNA IVT Templates with Extended Encoded Poly(A) Sequences. Mol. Ther. Nucleic Acids 2016, 5, e306. [CrossRef]

41. Meador, J.W., 3rd; McElroy, H.E.; Pasloske, B.L.; Milburn, S.C.; Winkler, M.M. pTRIPLEscript: A novel cloning vector for generating in vitro transcripts from tandem promoters for SP6, T7 and T3 RNA polymerase. Biotechniques 1995, 18, 152-157.

42. Mauro, V.P.; Chappell, S.A. A critical analysis of codon optimization in human therapeutics. Trends Mol. Med. 2014, 20, 604-613. [CrossRef]

43. Scholten, K.B.; Kramer, D.; Kueter, E.W.; Graf, M.; Schoedl, T.; Meijer, C.J.; Schreurs, M.W.; Hooijberg, E. Codon modification of T cell receptors allows enhanced functional expression in transgenic human T cells. Clin. Immunol. 2006, 119, 135-145. [CrossRef]

44. De Felipe, P. Polycistronic viral vectors. Curr. Gene Ther. 2002, 2, 355-378. [CrossRef] [PubMed]

45. Yang, Y.; Wang, Z. IRES-mediated capindependent translation, a path leading to hidden proteome. J. Mol. Cell Biol. 2019, 11, 911-919. [CrossRef]

46. Kim, J.H.; Lee, S.R.; Li, L.H.; Park, H.J.; Park, J.H.; Lee, K.Y.; Kim, M.K.; Shin, B.A.; Choi, S.Y. High cleavage efficiency of a 2A peptide derived from porcine teschovirus-1 in human cell lines, zebrafish and mice. PLoS ONE 2011, 6, e18556. [CrossRef]

47. Leisegang, M.; Engels, B.; Meyerhuber, P.; Kieback, E.; Sommermeyer, D.; Xue, S.A.; Reuss, S.; Stauss, H.; Uckert, W. Enhanced functionality of T cell receptor-redirected T cells is defined by the transgene cassette. J. Mol. Med. 2008, 86, 573-583. [CrossRef] [PubMed]

48. Liu, Z.; Chen, O.; Wall, J.B.J.; Zheng, M.; Zhou, Y.; Wang, L.; Ruth Vaseghi, H.; Qian, L.; Liu, J. Systematic comparison of 2A peptides for cloning multi-genes in a polycistronic vector. Sci. Rep. 2017, 7, 2193. [CrossRef]

49. De Felipe, P.; Luke, G.A.; Brown, J.D.; Ryan, M.D. Inhibition of 2A-mediated 'cleavage' of certain artificial polyproteins bearing N-terminal signal sequences. Biotechnol. J. 2010, 5, 213-223. [CrossRef]

50. Minskaia, E.; Ryan, M.D. Protein coexpression using FMDV 2A: Effect of “linker" residues. Biomed. Res. Int. 2013, $2013,291730$. [CrossRef]

51. Yang, S.; Cohen, C.J.; Peng, P.D.; Zhao, Y.; Cassard, L.; Yu, Z.; Zheng, Z.; Jones, S.; Restifo, N.P.; Rosenberg, S.A.; et al. Development of optimal bicistronic lentiviral vectors facilitates high-level TCR gene expression and robust tumor cell recognition. Gene Ther. 2008, 15, 1411-1423. [CrossRef]

52. Chng, J.; Wang, T.; Nian, R.; Lau, A.; Hoi, K.M.; Ho, S.C.; Gagnon, P.; Bi, X.; Yang, Y. Cleavage efficient 2A peptides for high level monoclonal antibody expression in CHO cells. MAbs 2015, 7, 403-412. [CrossRef]

53. Fang, J.; Qian, J.J.; Yi, S.; Harding, T.C.; Tu, G.H.; VanRoey, M.; Jooss, K. Stable antibody expression at therapeutic levels using the 2A peptide. Nat. Biotechnol. 2005, 23, 584-590. [CrossRef] [PubMed]

54. Van Driessche, A.; Van de Velde, A.L.; Nijs, G.; Braeckman, T.; Stein, B.; De Vries, J.M.; Berneman, Z.N.; Van Tendeloo, V.F. Clinical-grade manufacturing of autologous mature mRNA-electroporated dendritic cells and safety testing in acute myeloid leukemia patients in a phase I dose-escalation clinical trial. Cytotherapy 2009, 11, 653-668. [CrossRef]

55. European Commission. Directive 2001/83/EC of the European Parliament and of the Council of 6 November 2001 on the Community Code Relating to Medicinal Products for Human Use. 2001. EU law (EUR-Lex), ELI. 2001. Available online: http:/ / data.europa.eu/eli/dir/2001/83/2012-11-16 (accessed on 19 November 2020).

56. European Commission. Commission Directive 2005/28/EC of 8 April 2005 Laying Down Principles and Detailed Guidelines for Good Clinical Practice as Regards Investigational Medicinal Products for Human Use, as Well as the Requirements for Authorisation of the Manufacturing or Importation of Such Products. EU law (EUR-Lex), ELI. 2005. Available online: http: / / data.europa.eu/eli/dir/2005/28/oj (accessed on 19 November 2020).

57. European Commission. Commission Directive 2003/94/EC of 8 October 2003 Laying down the Principles and Guidelines of Good Manufacturing Practice in Respect of Medicinal Products for Human Use and Investigational Medicinal Products for Human Use. Retrieved from EU Law (EUR-Lex), ELI. 2003. Available online: http:/ / data.europa.eu/eli/dir/2003/94/oj (accessed on 19 November 2020).

58. EMA. CPMP/ICH/381/95-ICH Harmonised Tripartite Guideline-Validation of Analytical Procedures: Text and Methodology Q2(R1). Available online: https:/ / www.ema.europa.eu/en/ich-q2-r1-validation-analytical-procedures-text-methodology (accessed on 4 November 2020). 
59. Annunziata, C.M.; Ghobadi, A.; Pennella, E.J.; Vanas, J.; Powell, C.; Pavelova, M.; Wagner, C.; Kuo, M.; Ullmann, C.D.; Hassan, R.; et al. Feasibility and preliminary safety and efficacy of first-in-human intraperitoneal delivery of MCY-M11, anti-humanmesothelin CAR mRNA transfected into peripheral blood mononuclear cells, for ovarian cancer and malignant peritoneal mesothelioma. J. Clin. Oncol. 2020, 38, 3014. [CrossRef]

60. Derdelinckx, J.; Mansilla, M.J.; De Laere, M.; Lee, W.P.; Navarro-Barriuso, J.; Wens, I.; Nkansah, I.; Daans, J.; De Reu, H.; Jolanta Keliris, A.; et al. Clinical and immunological control of experimental autoimmune encephalomyelitis by tolerogenic dendritic cells loaded with MOG-encoding mRNA. J. Neuroinflamm. 2019, 16, 167. [CrossRef]

61. Chung, D.J.; Carvajal, R.D.; Postow, M.A.; Sharma, S.; Pronschinske, K.B.; Shyer, J.A.; Singh-Kandah, S.; Dickson, M.A.; D’Angelo, S.P.; Wolchok, J.D.; et al. Langerhans-type dendritic cells electroporated with TRP-2 mRNA stimulate cellular immunity against melanoma: Results of a phase I vaccine trial. Oncoimmunology 2017, 7, e1372081. [CrossRef]

62. Aarntzen, E.H.; Schreibelt, G.; Bol, K.; Lesterhuis, W.J.; Croockewit, A.J.; de Wilt, J.H.; van Rossum, M.M.; Blokx, W.A.; Jacobs, J.F.; Duiveman-de Boer, T.; et al. Vaccination with mRNA-electroporated dendritic cells induces robust tumor antigen-specific CD4+ and CD8+ T cells responses in stage III and IV melanoma patients. Clin. Cancer Res. 2012, 18, 5460-5470. [CrossRef] [PubMed]

63. Vik-Mo, E.O.; Nyakas, M.; Mikkelsen, B.V.; Moe, M.C.; Due-Tonnesen, P.; Suso, E.M.; Saeboe-Larssen, S.; Sandberg, C.; Brinchmann, J.E.; Helseth, E.; et al. Therapeutic vaccination against autologous cancer stem cells with mRNA-transfected dendritic cells in patients with glioblastoma. Cancer Immunol. Immunother. 2013, 62, 1499-1509. [CrossRef]

64. Suso, E.M.; Dueland, S.; Rasmussen, A.M.; Vetrhus, T.; Aamdal, S.; Kvalheim, G.; Gaudernack, G. hTERT mRNA dendritic cell vaccination: Complete response in a pancreatic cancer patient associated with response against several hTERT epitopes. Cancer Immunol. Immunother. 2011, 60, 809-818. [CrossRef] [PubMed]

65. Saeboe-Larssen, S.; Fossberg, E.; Gaudernack, G. mRNA-based electrotransfection of human dendritic cells and induction of cytotoxic T lymphocyte responses against the telomerase catalytic subunit (hTERT). J. Immunol. Methods 2002, 259, 191-203. [CrossRef]

66. Bol, K.F.; Aarntzen, E.H.; Pots, J.M.; Olde Nordkamp, M.A.; van de Rakt, M.W.; Scharenborg, N.M.; de Boer, A.J.; van Oorschot, T.G.; Croockewit, S.A.; Blokx, W.A.; et al. Prophylactic vaccines are potent activators of monocyte-derived dendritic cells and drive effective anti-tumor responses in melanoma patients at the cost of toxicity. Cancer Immunol. Immunother. 2016, 65, 327-339. [CrossRef]

67. Wilgenhof, S.; Van Nuffel, A.M.T.; Benteyn, D.; Corthals, J.; Aerts, C.; Heirman, C.; Van Riet, I.; Bonehill, A.; Thielemans, K.; Neyns, B. A phase IB study on intravenous synthetic mRNA electroporated dendritic cell immunotherapy in pretreated advanced melanoma patients. Ann. Oncol. 2013, 24, 2686-2693. [CrossRef]

68. Wilgenhof, S.; Corthals, J.; Heirman, C.; Neyns, B.; Thielemans, K. Clinical trials with MRNA electroporated dendritic cells for stage III/IV melanoma patients. J. Immunother. Cancer 2015, 3, P211. [CrossRef]

69. De Keersmaecker, B.; Claerhout, S.; Carrasco, J.; Bar, I.; Corthals, J.; Wilgenhof, S.; Neyns, B.; Thielemans, K. TriMix and tumor antigen mRNA electroporated dendritic cell vaccination plus ipilimumab: Link between T-cell activation and clinical responses in advanced melanoma. J. Immunother. Cancer 2020, 8, e000329. [CrossRef]

70. Borch, T.H.; Engell-Noerregaard, L.; Zeeberg Iversen, T.; Ellebaek, E.; Met, O.; Hansen, M.; Andersen, M.H.; Thor Straten, P.; Svane, I.M. mRNA-transfected dendritic cell vaccine in combination with metronomic cyclophosphamide as treatment for patients with advanced malignant melanoma. Oncoimmunology 2016, 5, e1207842. [CrossRef]

71. Bol, K.; van den Bosch, T.; Schreibelt, G.; Punt, C.; Figdor, C.; Paridaens, D.; de Vries, J. Adjuvant dendritic cell vaccination in high-risk uveal melanoma patients. J. Immunother. Cancer 2015, 3, P127. [CrossRef]

72. Amin, A.; Dudek, A.; Logan, T.; Lance, R.S.; Holzbeierlein, J.M.; Williams, W.L.; Jain, R.; Chew, T.G.; Nicolette, C.A.; Figlin, R.A.; et al. A phase II study testing the safety and activity of AGS-003 as an immunotherapeutic in subjects with newly diagnosed advanced stage renal cell carcinoma (RCC) in combination with sunitinib. J. Clin. Oncol. 2010, 28, 4588. [CrossRef]

73. Amin, A.; Dudek, A.Z.; Logan, T.F.; Lance, R.S.; Holzbeierlein, J.M.; Knox, J.J.; Master, V.A.; Pal, S.K.; Miller, W.H., Jr.; Karsh, L.I.; et al. Survival with AGS-003, an autologous dendritic cell-based immunotherapy, in combination with sunitinib in unfavorable risk patients with advanced renal cell carcinoma (RCC): Phase 2 study results. J. Immunother. Cancer 2015, 3, 14. [CrossRef]

74. Figlin, R.A. Personalized immunotherapy (AGS-003) when combined with sunitinib for the treatment of metastatic renal cell carcinoma. Expert Opin. Biol. Ther. 2015, 15, 1241-1248. [CrossRef] [PubMed]

75. Figlin, R.A.; Tannir, N.M.; Uzzo, R.G.; Tykodi, S.S.; Chen, D.Y.T.; Master, V.; Kapoor, A.; Vaena, D.; Lowrance, W.; Bratslavsky, G.; et al. Results of the ADAPT Phase 3 Study of Rocapuldencel-T in Combination with Sunitinib as First-Line Therapy in Patients with Metastatic Renal Cell Carcinoma. Clin. Cancer Res. 2020, 26, 2327-2336. [CrossRef]

76. Batich, K.A.; Reap, E.A.; Archer, G.E.; Sanchez-Perez, L.; Nair, S.K.; Schmittling, R.J.; Norberg, P.; Xie, W.; Herndon, J.E., 2nd; Healy, P.; et al. Long-term Survival in Glioblastoma with Cytomegalovirus pp65-Targeted Vaccination. Clin. Cancer Res. 2017, 23, 1898-1909. [CrossRef]

77. Mitchell, D.A.; Batich, K.A.; Gunn, M.D.; Huang, M.N.; Sanchez-Perez, L.; Nair, S.K.; Congdon, K.L.; Reap, E.A.; Archer, G.E.; Desjardins, A.; et al. Tetanus toxoid and CCL3 improve dendritic cell vaccines in mice and glioblastoma patients. Nature 2015, 519, 366-369. [CrossRef]

78. Lesterhuis, W.J.; De Vries, I.J.; Schreibelt, G.; Schuurhuis, D.H.; Aarntzen, E.H.; De Boer, A.; Scharenborg, N.M.; Van De Rakt, M.; Hesselink, E.J.; Figdor, C.G.; et al. Immunogenicity of dendritic cells pulsed with CEA peptide or transfected with CEA mRNA for vaccination of colorectal cancer patients. Anticancer Res. 2010, 30, 5091-5097. 
79. Berneman, Z.N.; Germonpre, P.; Huizing, M.T.; Velde, A.V.D.; Nijs, G.; Stein, B.; Tendeloo, V.F.V.; Lion, E.; Smits, E.L.; Anguille, S. Dendritic cell vaccination in malignant pleural mesothelioma: A phase I/II study. J. Clin. Oncol. 2014, 32, 7583. [CrossRef]

80. Kongsted, P.; Ellebæk, E.; Borch, T.H.; Iversen, T.Z.; Andersen, R.; Met, Ö.; Hansen, M.; Sengeløv, L.; Svane, I.M. Dendritic cell vaccination in combination with docetaxel for patients with prostate cancer - a randomized phase II study. Ann. Oncol. 2016, 27, vi371. [CrossRef]

81. Van Tendeloo, V.F.; Van de Velde, A.; Van Driessche, A.; Cools, N.; Anguille, S.; Ladell, K.; Gostick, E.; Vermeulen, K.; Pieters, K.; Nijs, G.; et al. Induction of complete and molecular remissions in acute myeloid leukemia by Wilms' tumor 1 antigen-targeted dendritic cell vaccination. Proc. Natl. Acad. Sci. USA 2010, 107, 13824-13829. [CrossRef] [PubMed]

82. Anguille, S.; Van de Velde, A.L.; Smits, E.L.; Van Tendeloo, V.F.; Juliusson, G.; Cools, N.; Nijs, G.; Stein, B.; Lion, E.; Van Driessche, A.; et al. Dendritic cell vaccination as postremission treatment to prevent or delay relapse in acute myeloid leukemia. Blood 2017, 130, 1713-1721. [CrossRef] [PubMed]

83. Khoury, H.J.; Collins, R.H., Jr.; Blum, W.; Stiff, P.S.; Elias, L.; Lebkowski, J.S.; Reddy, A.; Nishimoto, K.P.; Sen, D.; Wirth, E.D., 3rd; et al. Immune responses and long-term disease recurrence status after telomerase-based dendritic cell immunotherapy in patients with acute myeloid leukemia. Cancer 2017, 123, 3061-3072. [CrossRef] [PubMed]

84. Khoury, H.; Collins, R.; Blum, W.; Stiff, P.; Lebkowski, J.; Wirth, E.D.; Nishimoto, K.; DiPersio, J. Long-term follow-up of patients with acute myelogenous leukemia receiving an autologous telomerase-based dendritic cell vaccine. J. Clin. Oncol. 2015, 33, 7007. [CrossRef]

85. Lichtenegger, F.S.; Schnorfeil, F.M.; Rothe, M.; Deiser, K.; Altmann, T.; Bucklein, V.L.; Kohnke, T.; Augsberger, C.; Konstandin, N.P.; Spiekermann, K.; et al. Toll-like receptor 7/8-matured RNA-transduced dendritic cells as post-remission therapy in acute myeloid leukaemia: Results of a phase I trial. Clin. Transl. Immunol. 2020, 9, e1117. [CrossRef]

86. Frauke, S.; Felix, L.; Christiane, G.; Reinhard, H.; Beate, W.; Iris, B.; Gunnar, K.; Dolores, S.; Wolfgang, H.; Marion, S. ITOC2Vaccination with next-generation dendritic cells for AML postremission therapy induces antigen-specific T cell responses. Eur. J. Cancer 2015, 51, S8. [CrossRef]

87. Schnorfeil, F.; Lichtenegger, F.; Geiger, C.; Köhnke, T.; Bücklein, V.; Altmann, T.; Wagner, B.; Henschler, R.; Bigalke, I.; Kvalheim, G.; et al. Next-generation dendritic cells for immunotherapy of acute myeloid leukemia. J. Immunother. Cancer 2014, 2 , P84. [CrossRef]

88. Routy, J.P.; Nicolette, C. Arcelis AGS-004 dendritic cell-based immunotherapy for HIV infection. Immunotherapy 2010, 2, 467-476. [CrossRef] [PubMed]

89. Gay, C.L.; DeBenedette, M.A.; Tcherepanova, I.Y.; Gamble, A.; Lewis, W.E.; Cope, A.B.; Kuruc, J.D.; McGee, K.S.; Kearney, M.F.; Coffin, J.M.; et al. Immunogenicity of AGS-004 Dendritic Cell Therapy in Patients Treated During Acute HIV Infection. AIDS Res. Hum. Retrovir. 2018, 34, 111-122. [CrossRef]

90. Gay, C.L.; Kuruc, J.D.; Falcinelli, S.D.; Warren, J.A.; Reifeis, S.A.; Kirchherr, J.L.; James, K.S.; Dewey, M.G.; Helms, A.; Allard, B.; et al. Assessing the impact of AGS-004, a dendritic cell-based immunotherapy, and vorinostat on persistent HIV-1 Infection. Sci. Rep. 2020, 10, 5134. [CrossRef]

91. Routy, J.P.; Boulassel, M.R.; Yassine-Diab, B.; Nicolette, C.; Healey, D.; Jain, R.; Landry, C.; Yegorov, O.; Tcherepanova, I.; Monesmith, T.; et al. Immunologic activity and safety of autologous HIV RNA-electroporated dendritic cells in HIV-1 infected patients receiving antiretroviral therapy. Clin. Immunol. 2010, 134, 140-147. [CrossRef]

92. Jacobson, J.M.; Routy, J.P.; Welles, S.; DeBenedette, M.; Tcherepanova, I.; Angel, J.B.; Asmuth, D.M.; Stein, D.K.; Baril, J.G.; McKellar, M.; et al. Dendritic Cell Immunotherapy for HIV-1 Infection Using Autologous HIV-1 RNA: A Randomized, DoubleBlind, Placebo-Controlled Clinical Trial. J. Acquir. Immune Defic. Syndr. 2016, 72, 31-38. [CrossRef]

93. Gandhi, R.T.; Kwon, D.S.; Macklin, E.A.; Shopis, J.R.; McLean, A.P.; McBrine, N.; Flynn, T.; Peter, L.; Sbrolla, A.; Kaufmann, D.E.; et al. Immunization of HIV-1-Infected Persons With Autologous Dendritic Cells Transfected With mRNA Encoding HIV-1 Gag and Nef: Results of a Randomized, Placebo-Controlled Clinical Trial. J. Acquir. Immune Defic. Syndr. 2016, 71, 246-253. [CrossRef]

94. Allard, S.D.; De Keersmaecker, B.; de Goede, A.L.; Verschuren, E.J.; Koetsveld, J.; Reedijk, M.L.; Wylock, C.; De Bel, A.V.; Vandeloo, J.; Pistoor, F.; et al. A phase I/IIa immunotherapy trial of HIV-1-infected patients with Tat, Rev and Nef expressing dendritic cells followed by treatment interruption. Clin. Immunol. 2012, 142, 252-268. [CrossRef] [PubMed]

95. Van Craenenbroeck, A.H.; Smits, E.L.; Anguille, S.; Van de Velde, A.; Stein, B.; Braeckman, T.; Van Camp, K.; Nijs, G.; Ieven, M.; Goossens, H.; et al. Induction of cytomegalovirus-specific T cell responses in healthy volunteers and allogeneic stem cell recipients using vaccination with messenger RNA-transfected dendritic cells. Transplantation 2015, 99, 120-127. [CrossRef]

96. Maus, M.V.; Haas, A.R.; Beatty, G.L.; Albelda, S.M.; Levine, B.L.; Liu, X.; Zhao, Y.; Kalos, M.; June, C.H. T cells expressing chimeric antigen receptors can cause anaphylaxis in humans. Cancer Immunol. Res. 2013, 1, 26-31. [CrossRef]

97. Zhao, Y.; Moon, E.; Carpenito, C.; Paulos, C.M.; Liu, X.; Brennan, A.L.; Chew, A.; Carroll, R.G.; Scholler, J.; Levine, B.L.; et al. Multiple injections of electroporated autologous T cells expressing a chimeric antigen receptor mediate regression of human disseminated tumor. Cancer Res. 2010, 70, 9053-9061. [CrossRef] [PubMed]

98. Beatty, G.L.; Haas, A.R.; Maus, M.V.; Torigian, D.A.; Soulen, M.C.; Plesa, G.; Chew, A.; Zhao, Y.; Levine, B.L.; Albelda, S.M.; et al. Mesothelin-specific chimeric antigen receptor mRNA-engineered T cells induce anti-tumor activity in solid malignancies. Cancer Immunol. Res. 2014, 2, 112-120. [CrossRef] [PubMed] 
99. Beatty, G.L.; O’Hara, M.H.; Lacey, S.F.; Torigian, D.A.; Nazimuddin, F.; Chen, F.; Kulikovskaya, I.M.; Soulen, M.C.; McGarvey, M.; Nelson, A.M.; et al. Activity of Mesothelin-Specific Chimeric Antigen Receptor T Cells Against Pancreatic Carcinoma Metastases in a Phase 1 Trial. Gastroenterology 2018, 155, 29-32. [CrossRef]

100. Beatty, G.L.; O’Hara, M.H.; Nelson, A.M.; McGarvey, M.; Torigian, D.A.; Lacey, S.F.; Melenhorst, J.J.; Levine, B.; Plesa, G.; June, C.H. Safety and antitumor activity of chimeric antigen receptor modified T cells in patients with chemotherapy refractory metastatic pancreatic cancer. J. Clin. Oncol. 2015, 33, 3007. [CrossRef]

101. Tchou, J.; Zhao, Y.; Levine, B.L.; Zhang, P.J.; Davis, M.M.; Melenhorst, J.J.; Kulikovskaya, I.; Brennan, A.L.; Liu, X.; Lacey, S.F.; et al. Safety and Efficacy of Intratumoral Injections of Chimeric Antigen Receptor (CAR) T Cells in Metastatic Breast Cancer. Cancer Immunol. Res. 2017, 5, 1152-1161. [CrossRef]

102. Shah, P.D.; Huang, A.C.C.; Xu, X.; Zhang, P.J.; Orlowski, R.; Matlawski, T.; Shea, J.; Cervini, A.; Amaravadi, R.K.; Tchou, J.C.; et al. Phase I trial of autologous cMET-directed CAR-t cells administered intravenously in patients with melanoma \& breast carcinoma. J. Clin. Oncol. 2020, 38, 10035. [CrossRef]

103. Tan, A.T.; Yang, N.; Lee Krishnamoorthy, T.; Oei, V.; Chua, A.; Zhao, X.; Tan, H.S.; Chia, A.; Le Bert, N.; Low, D.; et al. Use of Expression Profiles of HBV-DNA Integrated Into Genomes of Hepatocellular Carcinoma Cells to Select T Cells for Immunotherapy. Gastroenterology 2019, 156, 1862-1876.E9. [CrossRef] [PubMed]

104. Koh, S.; Shimasaki, N.; Suwanarusk, R.; Ho, Z.Z.; Chia, A.; Banu, N.; Howland, S.W.; Ong, A.S.; Gehring, A.J.; Stauss, H.; et al. A practical approach to immunotherapy of hepatocellular carcinoma using T cells redirected against hepatitis B virus. Mol. Ther. Nucleic Acids 2013, 2, e114. [CrossRef] [PubMed]

105. Chen, W.; Cheng, J.; Zheng, X.; Yang, F.; Fam, R.; Koh, S.; Wai, L.-E.; Wang, T.; Bertoletti, A.; Zhang, Q. 273 Phase i study of LioCyx-M, autologous hepatitis B virus (HBV)-specific T cell receptor (TCR) T-cells, in recurrent HBV-related hepatocellular carcinoma (HCC) post-liver transplantation. J. Immunother. Cancer 2020, 8, A167. [CrossRef]

106. Wang, F.-S.; Meng, F.; Jin, J.; Li, Y.; Wong, R.W.; Tan, A.T.; Wang, T.; Bertoletti, A. 272 Use of LioCyx-M, autologous hepatitis B virus (HBV)-Specific T cell receptor (TCR) T-cells, in advanced HBV-related hepatocellular carcinoma (HCC). J. Immunother. Cancer 2020, 8, A166-A167. [CrossRef]

107. Inderberg, E.M.; Walchli, S. Long-term surviving cancer patients as a source of therapeutic TCR. Cancer Immunol Immunother 2020, 69, 859-865. [CrossRef]

108. Inderberg, E.M.; Walchli, S.; Myhre, M.R.; Trachsel, S.; Almasbak, H.; Kvalheim, G.; Gaudernack, G. T cell therapy targeting a public neoantigen in microsatellite instable colon cancer reduces in vivo tumor growth. Oncoimmunology 2017, 6, e1302631. [CrossRef]

109. Svoboda, J.; Rheingold, S.R.; Gill, S.I.; Grupp, S.A.; Lacey, S.F.; Kulikovskaya, I.; Suhoski, M.M.; Melenhorst, J.J.; Loudon, B.; Mato, A.R.; et al. Nonviral RNA chimeric antigen receptor-modified T cells in patients with Hodgkin lymphoma. Blood 2018, 132, 1022-1026. [CrossRef]

110. Riet, T.; Holzinger, A.; Dorrie, J.; Schaft, N.; Schuler, G.; Abken, H. Nonviral RNA transfection to transiently modify T cells with chimeric antigen receptors for adoptive therapy. Methods Mol. Biol. 2013, 969, 187-201. [CrossRef]

111. Svoboda, J.; Rheingold, S.R.; Gill, S.I.; Grupp, S.A.; Lacey, S.F.; Melenhorst, J.J.; Kulikovskaya, I.; Loudon, B.; Kerr, N.; Marcucci, K.T.; et al. Pilot Study of Non-Viral, RNA-Redirected Autologous Anti-CD19 Chimeric Antigen Receptor Modified T-Cells in Patients with Refractory/Relapsed Hodgkin Lymphoma (HL). Blood 2017, 130, 653. [CrossRef]

112. Poon, M.; Linn, Y.C.; Shimasaki, N.; Tan, L.K.; Koh, L.P.; Coustan-Smith, E.; Campana, D. A First-in-Human Study of Autologous T Lymphocytes with Antibody-Dependent Cell Cytotoxicity (ADCC) in Patients with B-Cell Non-Hodgkin Lymphoma (NHL). Blood 2016, 128, 3031. [CrossRef]

113. Tasian, S.K.; Kenderian, S.S.; Shen, F.; Ruella, M.; Shestova, O.; Kozlowski, M.; Li, Y.; Schrank-Hacker, A.; Morrissette, J.J.D.; Carroll, M.; et al. Optimized depletion of chimeric antigen receptor T cells in murine xenograft models of human acute myeloid leukemia. Blood 2017, 129, 2395-2407. [CrossRef]

114. Barrett, D.M.; Liu, X.; Jiang, S.; June, C.H.; Grupp, S.A.; Zhao, Y. Regimen-specific effects of RNA-modified chimeric antigen receptor T cells in mice with advanced leukemia. Hum. Gene Ther. 2013, 24, 717-727. [CrossRef]

115. Cummins, K.D.; Frey, N.; Nelson, A.M.; Schmidt, A.; Luger, S.; Isaacs, R.E.; Lacey, S.F.; Hexner, E.; Melenhorst, J.J.; June, C.H.; et al. Treating Relapsed / Refractory (RR) AML with Biodegradable Anti-CD123 CAR Modified T Cells. Blood 2017, 130, 1359. [CrossRef]

116. Lin, L.; Cho, S.F.; Xing, L.; Wen, K.; Li, Y.; Yu, T.; Hsieh, P.A.; Chen, H.; Kurtoglu, M.; Zhang, Y.; et al. Preclinical evaluation of CD8+ anti-BCMA mRNA CAR T cells for treatment of multiple myeloma. Leukemia 2020. [CrossRef]

117. Lin, L.; Xing, L.; Cho, S.-F.; Wen, K.; Hsieh, P.A.; Kurtoglu, M.; Zhang, Y.; Stewart, C.A.; Anderson, K.C.; Tai, Y.-T. Preclinical Evaluation of CD8+ Anti-Bcma mRNA CAR T-Cells for the Control of Human Multiple Myeloma. Blood 2019, $134,1811$. [CrossRef]

118. Tebas, P.; Jadlowsky, J.K.; Shaw, P.A.; Tian, L.; Esparza, E.; Brennan, A.; Kim, S.; Naing, S.Y.; Richardson, M.W.; Vogel, A.N.; et al. CCR5-edited CD4 T cells augment HIV-specific immunity to enable post rebound control of HIV replication. J. Clin. Investig. 2021. [CrossRef]

119. Xiao, L.; Cen, D.; Gan, H.; Sun, Y.; Huang, N.; Xiong, H.; Jin, Q.; Su, L.; Liu, X.; Wang, K.; et al. Adoptive Transfer of NKG2D CAR mRNA-Engineered Natural Killer Cells in Colorectal Cancer Patients. Mol. Ther. 2019, 27, 1114-1125. [CrossRef] 